\title{
Hanefî Hukukunda Ebeveyne Karşı Nafaka Sorumluluğu
}

\author{
Kamil Yelek \\ Dr. Öğr. Üyesi, Kırklareli Üniversitesi (ROR ID: 00jb0e673) \\ İlahiyat Fakültesi, İslam Hukuku Anabilim Dalı \\ Assist. Prof. Dr., Kurklareli University Faculty of Theology \\ Department of Islamic Law \\ Kırklareli/Turkey \\ kamilyelek@klu.edu.tr \\ ORCID: 0000-0002-8181-2494
}

\section{The Obligation of Financial Support (Alimony) to Parents in The Ḥanafi Law}

\section{Abstract}

Developments in the social, cultural and economic fields in the modern period have brought about changes in social values. The family institution, which is the most fundamental building block of society, is one of the areas where this change is experienced. With modernization, the disintegration of extended family structures and their replacement by nuclear families and the acceleration of this process with the participation of women in business life has seriously changed the position of the elderly in the family and society. This change in the structure of the family has caused elderly and needy parents to live away from their children and grandchildren, or to be doomed to isolation in nursing homes away from warm family circle and social environment. The increasing number of these institutions which are not a product of Islamic civilization and the number of people living here disturbs everybody with a conscience. This situation requires revealing the necessity of protecting the elders of the family, protecting and taking care of them and providing their alimony in case of need in terms of Islamic law, and reminding our responsibilities in this regard. Due to the justification aforementioned, the alimony responsibility of children towards the their parents and grandparents will be discussed in this study.

There have been some studies on alimony in Islamic law. However, while the alimony of the ascendant/usūl (parents and grandparents) is presented as a chapter or subtitle in some of these studies, the practical applications of this issue have not been touched on in other studies. Whereas, a study that does not take into account the practical application of the law, will be incomplete. For this reason, it is necessary to reveal how the theoretical knowledge discussed in the classical fiqh books about the alimony of the ascendant is applied in practice.

Furthermore, the studies conducted so far about the alimony of the ascendant have been handled with a cross-sectarian approach. However, this mentioned situation does not quite coincide with the legal activity style in traditional fiqh thought. Therefore, it would be more appropriate to read the views on the relevant subject through the literature of a particular

İtihal Taraması/Plagiarism Detection: Bu makale intihal taramasından geçirildi/This paper was checked for plagiarism Etik Beyan/Ethical Statement: Bu çalışmanın hazırlanma sürecinde bilimsel ve etik ilkelere uyulduğu ve yararlanılan tüm çalışmaların kaynakçada belirtildiği beyan olunur/It is declared that scientific and ethical principles have been followed while carrying out and writing this study and that all the sources used have been properly cited (Kamil Yelek).

Geliş/Received: 31 Mayıs/May 2021 | Kabul/Accepted: 30 Ağustos/August 2021 | Yayın/Published: 20 Eylül/September 2021 Atuf/Cite as: Kamil Yelek, "Hanefî Hukukunda Ebeveyne Karşı Nafaka Sorumluluğu = The Obligation of Financial Support (Alimony) to Parents in The Ḥanafí Law", Eskiyeni 44 (Eylül/September 2021), 585-610. https://doi.org/10.37697/eskiyeni.945873 CC BY-NC 4.0 | This paper is licensed under a Creative Commons Attribution-NonCommercial License 
madhab/sect or school. Because, the legal situation of an issue has been handled within the furū' al-fiqh systematic of each madhab in traditional fiqh thought and the system has been operated in this way.

For this reason, we will try to handle this study where we will examine the alimony responsibility of children towards their parents and grandparents, based on the sources of the Hanafi School. In this context, first of all, the definition of alimony and its types and the rules on the subject will be presented. Then, it will be revealed whether there is a change within the Hanafi school in the issue of the alimony of the parents, how the views put forward previously were reflected in the Ottoman fatwā collections, how these views were applied in practice based on the Ottoman sharía court records and how the alimony of the parents was handled in Turkish Civil Law.

\section{Keywords}

Islamic Law, Alimony Law, Responsibility, Parents, Children, Kinship in the direct line

\section{Öz}

\section{Hanefî Hukukunda Ebeveyne Karşı Nafaka Sorumluluğu}

Modern dönemde sosyal, kültürel ve ekonomik alanda meydana gelen gelişmeler, toplumsal değerlerdeki değişimleri de beraberinde getirmiştir. Toplumun en temel yapı taşı konumundaki aile kurumu da bu değişimin yaşandığı alanlardan birisidir. Modernleşme ile birlikte geniş aile yapılarının çözülerek yerini çekirdek ailelere bırakması ve kadının iş hayatına katılmasıyla bu sürecin daha da hızlanması, yaşlıların ailedeki ve toplumdaki konumunu ciddi şekilde değişikliğe uğratmıştır. Ailenin yapısında meydana gelen bu değişim, yaşlı ve bakıma muhtaç olan ebeveynlerin çocuklarından ve torunlarından uzak bir şekilde hayat sürmelerine ve sıcak bir aile ortamı ile sosyal çevrelerinden kopar(ılar)ak huzurevlerinde yalnızlığa mahkûm olmalarına yol açmıştır. İslam medeniyetinin bir ürünü olmayan bu kurumların ve burada yaşayan kişi sayısının her geçen gün artması, vicdan sahibi herkesi rahatsız etmektedir. Bu durum, İslam hukuku açısından aile büyüklerine sahip çımanın, onları koruyup kollamanın ve ihtiyaç halinde nafakalarını temin etmenin gereğini ortaya koymayı ve bu konudaki sorumluluklarımızı hatırlatmayı gerektirmektedir. Zikredilen gerekçe sebebiyle, bu çalışmada çocukların ebeveynlerine ve aile büyüklerine karşı nafaka sorumluluğu ele alınacaktır.

İslam hukukunda nafakayla ilgili birtakım çalışmalar yapılmış olsa da bunların bazısı usûlün (ana-baba, dede ve nine) nafakasını genel olarak ele alan çalışmaların içerisinde bir bölüm ya da alt başlık olarak sunarken, bazıları da meselenin pratik uygulamalarına hiç temas etmemektedir. Hâlbuki hukukun pratik uygulamasını dikkate almadan yapılan bir çalışma eksik olacaktır. Bu yüzden usûlün nafakasıyla ilgili klasik fıkıh kitaplarında ele alınan teorik bilginin pratikte nasıl uygulandığının ortaya konulması gerekmektedir.

Diğer taraftan usûlün nafakasıyla ilgili şimdiye kadar yapılan çalışmalar, daha ziyade mezhepler üstü bir yaklaşımla ele alınmıştır. Ancak zikredilen bu durum, geleneksel fikıh düşüncesindeki hukuki faaliyet tarzıyla pek örtüşmemektedir. Bu yüzden ilgili konudaki görüşleri belirli bir mezhep ya da ekolün literatürü üzerinden okumak daha isabetli olacaktır. Çünkü geleneksel fikıh düşüncesinde şerî̀ bir meselenin hükmü, her mezhebin kendi fürû-1 fikıh sistematiği içinde ele alınmış ve sistem bu şekilde işletilmiştir.

Yukarıda bahsettiğimiz sebeplerden dolayı çocukların ebeveynlerine ve aile büyüklerine karşı nafaka sorumluluğunu inceleyeceğimiz bu çalışmayı Hanefî mezhebinin kaynaklarından hareketle ele almaya çalışacağız. Bu bağlamda öncelikle nafakanın tanımı, türleri ve konuyla ilgili hükümler ele alınacaktır. Akabinde ise, usûlün nafakasıyla ilgili konularda Hanefî mezhebi 
içerisinde bir değişimin olup olmadığı, daha önce ileri sürülen görüşlerin Osmanlı fetvâ mecmuâlarına nasıl yansıdığı, Osmanlı şeriyye sicillerinden hareketle bunların pratikte nasıl uygulandığı ve usûlün nafakasının Türk Medeni Hukuku'ndaki mevcut durumu gösterilmeye çalışılacaktır.

\section{Anahtar Kelimeler}

İslam Hukuku, Nafaka Hukuku, Sorumluluk, Ebeveyn, Çocuklar, Üstsoy-Altsoy Hısımlığı.

\section{Giriş}

Modernite her alanı olduğu gibi aile kurumunun yapısını da ciddi bir şekilde etkilemiştir. Modernleşme ile birlikte geniş aile yapıları çözülerek yerini çekirdek ailelere bırakmış, kadının iş hayatına katılmasıyla bu süreç daha da hızlanmış ve nihayetinde aile kurumu yapısal ve kültürel bir değişime maruz kalmıştır. ${ }^{1}$ Söz konusu durum, yaşliların toplum ve aile içerisindeki konumunu derinden etkileyerek bir takım sosyal problemlere neden olmuştur.

Yaşanan bu değişimin birinci derecedeki mağdurları yaşlılar olmuştur. Zira yaşlı ve bakıma muhtaç olan kişiler önceki dönemlerde aile içerisinde hayatlarını sürdürürken, modern dönemde ailenin yapısında meydana gelen bu değişim ebeveynlerin çocuklarından, dede ve ninelerin de torunlarından uzak bir şekilde hayat sürmelerine ve sıcak bir aile ortamı ile sosyal çevrelerinden kopar(1lar)ak huzurevlerinde kalmalarına yol açmıştır.

Modernleşmenin bir sonucu olarak ortaya çıkan bu kurumların ve burada yaşayan kişilerin sayısı, ülkemizde her geçen gün artmaktadır. Aile, Çalışma ve Sosyal Hizmetler Bakanlığına bağlı olan Engelli ve Yaşlı Hizmetleri Genel Müdürlügü̈nün 2021 Şubat ayında yayınladığı bültendeki şu tablo bunu açık bir şekilde ortaya koymaktadır.

Tablo 1: Aile, Çalışma ve Sosyal Hizmetler Bakanlığına Bağlı Resmi Huzurevi Sayısı, Kapasitesi ve Huzurevlerinde Kalan Yaşlı Birey Sayısının Yıllara Göre Dağılımı

\begin{tabular}{lccc}
\hline \multicolumn{1}{c}{ Yıllar } & Huzurevi Sayısı & Kapasite & Bakılan Kişi Sayısı \\
\hline 2021 (Şubat) & 162 & 16.466 & 13.970 \\
\hline 2019 & 153 & 15.385 & 13.888 \\
\hline 2018 & 146 & 14.967 & 13.883 \\
\hline 2014 & 124 & 12.647 & 11.688 \\
\hline 2010 & 97 & 9.260 & 7.979 \\
\hline 2006 & 69 & 7.605 & 6.082 \\
\hline 2002 & 63 & 6.477 & 4.952
\end{tabular}

Tabloya bakıldığında Türkiye'de Bakanlığa bağlı resmi huzurevlerinin ve burada kalan kişi sayılarının hızlı bir şekilde arttığı rahatlıkla görülmektedir. Nitekim Bakanlığa bağlı resmi huzurevi sayısı 2002'de 63 iken, bu sayı 2021 Şubat ayı itibariyle

1 Emine Karslı, “Modernleşme Sürecinde Çözülen Aile Yapısı ve Kadının Yeniden İnşası”, Uluslararası Hukuk ve Sosyal Bilim Araştırmaları Dergisi 1/1 (Temmuz 2019), 1-14. 
162'ye ulaşmıştır. Bakılan yaşlı sayısı 2002'de 4.952 iken, 2021 Şubat ayındaki verilere göre 13.970 olmuştur. Ancak, rakamlar bunlarla da sınırlı değildir. Zira diğer kamu kuruluşlarına ait huzurevleri ile özel huzurevlerinin sayısı bu rakamlara dâhil edildiğinde, ülkedeki toplam huzurevi sayısı 445'e burada bakım hizmeti verilen kişi sayısı da 27.571 seviyelerine çıkmaktadır. ${ }^{2}$ Her geçen gün sayıların bu şekilde artması sorumlu ve vicdan sahibi olan herkesi rahatsız etmektedir. Söz konusu durum İslam hukuku açısından aile büyüklerine sahip çıkmanın, onları koruyup kollamanın ve ihtiyaç halinde nafakalarını temin etmenin gereğini ortaya koymayı ve bu konudaki sorumluluklarımızı hatırlatmayı gerektirmektedir. Zira ebeveyne karşı nafaka sorumluluğu günümüzün ihmal edilen en önemli konularındandır.

İslam hukukunda nafakayla ilgili birtakım çalışmalar yapılmış ${ }^{3}$ olsa da, bunların bazısı usûlün (ana-baba, dede ve nine) nafakasını genel olarak ele alan çalışmaların içerisinde bir bölüm ya da alt başlık olarak sunarken, bazıları da meselenin pratik uygulamalarını göz ardı etmiştir. Hukukun pratik uygulamasını dikkate almadan yapılan bir çalışma eksik olacağı için de usûlün nafakasıyla ilgili klasik fikıh kitaplarında ele alınan nazari bilginin pratikte nasıl uygulandığının ortaya konulması gerekir.

Yukarıda bahsettiğimiz sebeplerden dolayı çocukların ebeveynlerine karşı nafaka sorumluluğunu ele alacağımız bu çalışmayı Hanefi mezhebinin kaynaklarından hareketle incelemeye çalışacağız. Bu bağlamda öncelikle nafakanın tanımı, türleri ve konuyla ilgili hükümleri ele alınacaktır. Akabinde sunulan bilgilerin Osmanlı fetvâ mecmuâlarına nasıl yansıdı̆̆ı, şeriyye sicillerinden hareketle pratikte bunların nasıl uygulandığı ve usûlün nafakasının Türk Medeni Hukuku'ndaki mevcut durumu izah edilmeye çalışılacaktır.

\section{Nafakanin Tanımı}

Sözlükte "harcanan ve tüketilen şey" manasına gelen nafaka sözcüğü, "bir malı harcamak ve sarf etmek" anlamlarına gelen "infak" kelimesinden türetilen bir isimdir.

2 Aile, Çalışma ve Sosyal Hizmetler Bakanlığı Engelli ve Yaşlı Hizmetleri Genel Müdürlüğü (EYHGM), Engelli ve Yaşli İstatistik Bülteni (Şubat 2021), 50-51.

3 Ruhi Özcan, İslâm Hukuku’nda Hısımlık Nafakası (İzmir: Çağlayan Yayınları, 1996); Celâl Erbay, İslâm Hukuku'nda Evlilik ve Hısımlık Nafakası: Kitâbu'n-Nafakat ve Türk Yargı Kararları ile Mukayeseli Olarak (Bakü: Göytürk Neşriyat, 1995); Saffet Köse, "İslâm Açısından Ebeveynin Çocukları Üzerindeki Hakları veya Çocukların Ebeveynine Karşı Vazifeleri”, İslam Hukuku Araştırmaları Dergisi 12 (2008), 345-368; Üveys Ateş, "İslâm Hukukunda ve Türk Medeni Hukukunda Ergin Akrabaya Karşı Nafaka Yükümlülüğü”, FSM İlmi Araştırmalar İnsan ve Toplum Bilimleri Dergisi 13 (Haziran 2019 ), 1-31; Fethiye Birsen Kaymak-Ayten Erol, "İslâm Aile Hukukunda Hısımlık İlişkisi Bakımından Ebeveyn Nafakası", Kalemname 5/10 (Aralik 2020), 444-471.

4 İbn Manzûr, Muhammed b. Mükerrem, Lisânü'l-Arab, nşr. Emin Muhammed Abdülvehhâb, Muhammed es-Sadık el-Ubeydî (Beyrut: Dâru Sâdır, 1414), "nafaka”, 10/358; Ebü'l-Abbas Ahmed b. Muhammed b. Ali el-Hamevî el-Feyyûmî, el-Misbâhü'l-münîr fi Garîbi'ş-Şerhi'l-Kebîr (Beyrut: el-Mektebetü'l-İlmiyye, ts.) "nafaka", 2/618; Muhammed Revvâs Kal'acî-Hâmid Sâdık Kanîbî, Mu'cemü lugati'l-fukahâ (Beyrut: Dâru'n-Nefâis, 1408/1988), "nafaka”, 485; Sa'dî Ebû Ceyb, el-Kâmûsül'-fikhî luğaten ve istılâhan (Dımeşk: Dâru'l-Fikr, 1408/1988), "nafaka”, 358; Ebü'l-Feyz Murtazâ Muhammed b. Muhammed ez-Zebîdî, Tâcü'l- 
Hukuki bir terim olarak ise, nafaka "bir şeye kendisiyle hayatta kalacağı şeyleri vermek"5 veya "yiyecek giyecek ve barınma gibi hayatın sürdürülebilmesi kendisine bağlı olan şey" veyahut da "hayâtiyetin ve yararlanmanın devamlılı̆ını sağlamak için yapılması zorunlu olan harcamalar" gibi anlamlara gelir.

Nafaka sorumluluğu, şahısların yanı sıra kişinin mülkiyetinde bulunan canlı ve cansız varlıkları da kapsar. ${ }^{8}$ İslam hukukunda geniş anlamları olmakla birlikte Hanefîler nafaka terimini daha ziyade şahısların nafakasını kapsayacak şekilde kullanmıştır. Nitekim Hanefî hukukçuların bir kısmı nafakanın sözlükte "insanın ailesi için harcadığı şey” anlamına geldiğini ve şer'an bunun yiyecek, giyecek ve barınmadan ibaret olduğunu ifade etmektedirler. ${ }^{9}$ Mecelle'de yapilan "havâyice ve te'ayyüşe sarf olunacak akçe ve zâd ve zahîre makūlesidir" şeklindeki tanım da bunlara benzerdir..$^{10}$ Yapılan tanımlarda görüldüğü üzere nafaka, insanın varlığını sürdürebilmesi için kendi imkânlarıyla geçimini sağlayamayan ve yardım edilmediği takdirde yoksulluğa düşecek kişilerin ya da sorumluluğundaki diğer varlıkların temel ihtiyaçlarının (yiyecek, giyecek ve barınma gibi) karşılanmasını ifade eden bir terimdir.

\section{Nafakanın Türleri}

İslâm hukukuna göre bir kimse başkasının nafakasıyla ancak üç sebepten dolayı sorumlu olur. Nafaka eş nafakası (zevciyyet), akraba nafakası (karâbet) ve mülkiyet nafakası (milk) diye üçe ayrılmaktadır. ${ }^{11}$ Bunlardan zevciyet ile karâbet, aile hukuku

arûs min cevâhiri'l-kâmûs (Kuveyt: Dâru'l-Hidâye, ts.), "nafaka”, 26/430-436; Ömer Nasuhi Bilmen, Hukuku İslâmiyye ve Istılahatı Fıkhiyye Kamusu (İstanbul: Bilmen Yayınevi, 1968), 2/444-445; Celal Erbay, "Nafaka", Türkiye Diyanet Vakfi İslâm Ansiklopedisi (İstanbul: TDV Yayınları, 2006), 32/282.

5 Osmân b. Alî ez-Zeylaî, Tebyînül-hakâik fi Şerhi Kenzi'd-dekâik (Bulak: el-Matbaatü'l-Kübrâ el-Emiriyye, 1313), 3/50; Ekmelüddin Muhammed b. Mahmud el-Babertî, el-İnaye şerhu'l-hidâye (Beyrut: Dâru'l-Fikir, ts.), 4/378; Ebu Muhammed Bedreddin Mahmud b. Ahmed b. Musa el-Aynî el-Hanefî, el-Binâye fî şerhi'lhidâye (Beyrut: Dâru'l-Kütübi'l-İlmiyye, 1420), 5/659; Kemalüddîn İbnü'l-Hümâm, es-Sivâsî, Fethü'l-kadîr (Beyrut: Dâru'l-Fikr, ts.), 4/378; İbn Nüceym, Siracüddîn Ömer b. İbrahim, en-Nehrü'l-fâik Şerhu Kenzi'dDekâik, thk. Ahmed Azvu İnâye (Beyrut: Dâru'l-Kütübi'l-İlmiyye, 2002), 2/505.

6 Şeyhîzâde Damad Efendi, Mecmaü'l-enhur fî şerhi Mülteka'l-ebhur, thk. Halil İmran el-Mansur (Beyrut: Dârü'l-Kütübü'l-ílmiyye, 1998), 1/484.

7 Erbay, "Nafaka", 32/282.

8 Bilmen, Istılahatı Flkhiyye Kamusu, 2/444-517; Erbay, "Nafaka”, 32/282.

9 İbn Nüceym, Zeynüddîn b. İbrâhîm, Bahrü’r-râik şerhü Kenzi'd-Dekâik (Kahire: Dâru'l-Kitâbi'l-İslâmî, ts.), 4/188, İbn Nüceym, en-Nehrü'l-fâik, 2/504; Muhammed b. Ali b. Muhammed b. Ali b. Abdurrahman elHaskefî, ed-Dürrü'l-muhtâr şerhu Tenvîri'l-ebsâr ve câmi'i'l-bihâr, thk. Abdülmun'im Halil İbrahim (Beyrut: Dârü'l-Kütübi'l-i̇lmiyye, 2002), 1/257; İbn Âbidîn, Muhammed Emîn, Reddü'l-Muhtâr ale'd-Dürri'l-muhtâr (Beyrut: Dâru'l-Fikir,1412), 3/571; Abdulğanî el-Ğanimî ed-Dimeşkî el-Meydânî, el-Lübâb fî şerhi'l-kitâb, thk. Muhammed Muhyiddîn Abdülhamid (Beyrut: el-Mektebetü'l-illmiyye, ts.), 3/91

10 Ali Haydar Efendi, Küçük, Dürerül-hükkâm şerhu Mecelleti'l-ahkâm (İstanbul: Matbaaa-i Tevsi-i Tibaat, 1330), 3/ 226.

11 Babertî, el-İnâye, 4/378; Ebu Bekr Ali b. Muhammed el-Haddâdî, el-Cevheratü'n-Neyyira (el-Matbaatü'lHayriyye, 1322), 2/83; Aynî, el-Binâye, 5/659, İbnü'l-Hümâm, Fethü'l-kadîr, 4/378; İbn Nüceym, elBahru'r-râik, 4/188; İbn Nüceym, en-Nehrü'l-fâik, 2/505; Molla Hüsrev Muhammed b. Ferâmuz, Dürerü'l-hükkâm fi şerhi Gureri'l-ahkâm (Kahire: Dârû İhyâi'l-Kütübi'l-Arabiyye, ts.), 1/412; Damâd, Mecmaü'l-enhur, 1/484; Haskefî, ed-Dürrü'l-muhtâr, 1/257; İbn Âbidîn, Reddü'l-Muhtâr, 3/572, Meydânî, elLübâb, 3/91. 
ilişkilerinden kaynaklanmakta olup kişinin evlendiği kadın ile yoksul durumda olan akrabalarının geçim masraflarını; mülkiyet nafakası ise sahip olduğu canlı ve cansız varlıkların nafakasını temin etmeyi ifade etmektedir. ${ }^{12}$

Nafaka Türk Medeni Hukuku'nda ise, genel olarak "bakım ve yardım nafakası" diye ikiye, bakım nafakası da kendi içerisinde "tedbir, yoksulluk ve iştirak" nafakası olarak üç kısma ayrılmaktadır. ${ }^{13}$ Bakım nafakası, eşlerin birbirlerine ve çocuklarına karşı olan yükümlülükleri; yardım nafakası ise geçimini kendi imkânlarıyla sağlayamayan ve yardım edilmediği takdirde yoksulluğa düşecek kişilere yapılan mali yardımı ifade eder. $^{14}$

Görüldüğü üzere bu çalışmanın konusunu oluşturan ana-babaya (usûl) karşı nafaka yükümlülüğü, İslâm hukukunda hısımlık (karâbet) nafakası kapsamında ele alınırken; Türk Medeni Hukuku'nda ise yardım nafakasının içerisinde mütalaa edilmektedir.

\section{Ebeveyne Karş1 Nafaka Sorumluluğu}

İnsan, eşinin ve çocuklarının (fürû́) yanı sıra fakir ve muhtaç durumda olan ebeveynlerinin (usûl) nafakasından da sorumludur. Yardıma muhtaç olan anne ve babanın nafakasını karşılamak, her şeyden önce insani ve ahlaki bir yükümlülüktür. Ancak hukuk toplumun ve insanların menfaati için son derece önemli olan bu yükümlülüğü kişilerin inisiyatifine bırakmayarak nafaka sorumluluğunu kanuni bir ödev olarak belirtmiş, bunun için gereken düzenlemeleri yapmış ve gerektiğinde zorla ifasını da sağlamıştır. Dolayısıyla, ebeveyne karşı nafaka sorumluluğu ahlâkî bir görev olmanın da ötesinde bağlayıcılı̆̆ı olan hukuki bir yükümlülüktür. ${ }^{15}$

Ebeveyne karşı nafaka sorumluluğu, günümüz hukukunda çocukların mirastaki konumlarına göre düzenlenmiştir. Nitekim Türk Medeni Kanunu'nun 365. maddesinde belirtildiği üzere, nafaka davası kişilerin mirastaki sırası göz önünde tutularak açılmaktadır. ${ }^{16}$ Bu maddeye göre, nafaka alacaklısı olan ebeveynler öncelikle çocuklarına, onların bulunmaması durumunda da sırasıyla torunlarına ve aşağıya doğru altsoyuna başvurabilir. ${ }^{17}$ Çünkü kişinin fakir ve muhtaç durumda olan kendi üst soyunun nafakasını karşılaması kanuni bir zorunluluktur. Nitekim Türk Medeni Kanunu'nun 364. maddesinde, yardım edilmediği takdirde yoksulluğa düşecek olan üstsoyun nafakasından herkesin sorumlu olduğu açıkça bildirilmektedir. ${ }^{18}$ Ayrıca

12 Bilmen, Istılahatı Fikhiyye Kamusu, 2/444-517; Erbay, "Nafaka”, 282.

13 Necmeddin Feyzi Feyzioğlu, Aile Hukuku (İstanbul: Fakülteler Matbaası, 1979), 653-655; Turgut Akıntürk - Derya Ateş, Türk Medeni Hukuku Aile Hukuku (İstanbul, Beta Yayınları, 2019), 444; Ahmet Cemal Ruhi, Yargıtay İçtihatlarıyla Nafaka Hukuku (İstanbul, Seçkin Yayınları, 2010), 22.

14 Turgut Akıntürk, Türk Medeni Hukuku Aile Hukuku (İstanbul: Beta Yayınları, 2006), 456; Selahattin Sulhi Tekinay, Türk Aile Hukuku (İstanbul: Beta Basım Yayım Dağıtım, 1984), 609; Recep Çiğdem, Mukayeseli Medeni Hukuk (İstanbul: Rağbet Yayınları, 2012), 144; Feyzioğlu, Aile Hukuku, 655.

15 Ateş, "Ergin Akrabaya Karşı Nafaka Yükümlülüğü”, 1.

16 TMK, "Madde 365".

17 Ruhi, Yargıtay İçtihatlarıyla Nafaka Hukuku, 86; Ateş, “Ergin Akrabaya Karşı Nafaka Yükümlülüğü”, 22-23.

18 TMK, "Madde 364". 
Türk Medeni Hukuku'nda evlilik dışı ilişkiden doğan çocuk ile evlatlık edinilen kişi arasında soy bağı kurulabildiği için zikredilen kişiler arasında nafaka yükümlülüğü olabilmektedir. ${ }^{19}$ İslam hukukunda ise evlilik dişı ilişki ile evlatlık kurumu, soy bağının oluşmasına engel olduğu için söz konusu durumlar taraflar arasında nafaka yükümlülüğünü doğurmamaktadır. ${ }^{20}$

\subsection{Ebeveyne Karşı Nafaka Sorumluluğunun Şer’î Dayanakları}

Kur'an-1 Kerîm'deki birçok âyet ile Hz. Peygamber'den (s.a.v) nakledilen hadisler, fakir ve muhtaç durumda olan usûlün ihtiyaçlarının karşılanması gerektiğine somut bir şekilde işaret etmektedir. Özellikle İsrâ suresinin 23. âyeti, usûlun nafaka sorumluluğuna kaynak olarak gösterilen delillerden biridir. Bu âyette ana-babayı azarlamak ve onlara öf demek kesin bir dille yasaklanmıştır. Çünkü bu şekilde davranmak, ebeveyne eziyet vermek anlamına gelmektedir. Bu âyete dayanarak, muhtaç durumda olan ebeveyne ait ihtiyaçların alt soy tarafından temin edilmesi gerektiği ifade edilmektedir. Zira zengin olan bir kişinin muhtaç durumda olan ana-babasını çalışmak zorunda bırakması ve nafakalarını karşılamayarak onları böyle bir yükün altına sokması, öf demekten daha büyük bir eziyet olarak kabul edilmektedir. ${ }^{21}$

Sünnetten deliline gelince, Hz. Peygamber (s.a.v) bu konuda kişinin yediği şeylerin en güzelinin kendi kazancından olduğunu, evladının kazandığının da kendisininki gibi olması sebebiyle ihtiyaç durumunda çocukların mallarından yenilebileceğini ifade etmektedir. ${ }^{22}$ Başka bir hadiste belirtildiği üzere, sahabeden biri babasının kendi malından almak istediğini sorunca, Hz. Peygamber (s.a.v) bir babanın çocuğuna ait maldan alabileceğini söylemiştir. ${ }^{23}$ Bu hadislerde ifade edildiği üzere, babanın çocuklarına ait mallardan yararlanma hakkı vardır, ancak buradaki nafaka hakkını belirleyen şey ihtiyaçtır. Nitekim adamın biri Hz. Ebû Bekir'e gelerek babasının kendisine ait malın tamamını almak istediğini şikâyet etmiş, bunun üzerine Halife de babanın sadece ihtiyacı kadar alabileceğini ifade etmiştir. Sonrasında çocuğun babası "Hz. Peygamber (s.a.v) sen ve malın babana aittir buyurmuyor mu?" diye itiraz edince, Hz. Ebû Bekir: "Allah Resulü bu sözüyle senin nafakanı kastetmiştir, sen de Allah’ın senin hakkında razı olduğuna razı

19 TMK, "Madde 282"; Ruhi, Yargıtay İçtihatlarıyla Nafaka Hukuku, 79; Zümra Topuksak, Yardım Nafakası (İstanbul: İstanbul Üniversitesi, Sosyal Bilimler Enstitüsü, Yüksek Lisans Tezi, 2011), 13-15.

20 Nuri Kahveci, İslâm Aile Hukuku (İstanbul: Hikmetevi Yayınları, 2014), 151, 154, 155; Abdullah Çolak, İslâm Aile Hukuku (Malatya: Y1lmaz Yayıncilık, 2016), 170, 173.

21 Şemsü'l-eimme es-Serahsî, el-Mebsût (Beyrut: Dâru'l-Kütübi'l-İlmiyye, 1993), 5/222; Alâüddîn Ebû Bekir el-Kâsânî, Bedâiu's-sanâi' fi tertibi'ş-şerâit (Beyrut: Dâru'l-Kütübi'l-îlmiyye, 1986), 4/30, 35; Mevsılî, Mecdüddîn Abdullah b. Mahmûd, el-ìhtiyâr li-ta'îli'l-Muhtâr (Beyrut: Dâru'l-Kütübi'l-i̇lmiye, 1937/1356), 4/10; Zeylâî, Tebyînül-hakâik, 3/63.

22 Ebû Dâvud, "Büyûu”, 77; İbn Mâce, "Ticârât”, 1; Burhâneddîn el-Buhârî (Burhânüşşerîa), el-Muhîtu'lBurhânî fi'l-fikhi'n-Nu'mânî (Beyrut: Dâru'l-Kütübi'l-i̇lmiye 1424), 3/577; Kâsânî, Bedâiu's-sanâi', 4/30; Mevsilî, el-ìhtiyâr, 4/10.

23 Ebû Dâvud, "Büyû", 77; Ahmed b. Hanbel, el-Müsned, 2/179; İbn Mâce, "Ticârât", 1; Burhâneddîn elBuhârî, el-Muhîtu'l-Burhânî, 3/577; Kâsânî, Bedâiu's-sanâi', 4/30; Mevs1lî, el-i̇htiyâr, 4/10-11. 
ol." diye cevap vermiş̧ir. ${ }^{24} \mathrm{~Hz}$. Ebû Bekir'den aktarılan bu rivayet, babanın çocuğuna ait maldan dilediği gibi yararlanamayacağını, buradaki ölçünün ihtiyaç ile sınırlı olduğunu göstermektedir.

İslam hukukçuları yukarıda zikredilen bu âyet ve hadislere dayanarak muhtaç durumda olan anne ve babanın nafakasını karşılamanın gerekli (vücûb) olduğu hususunda ittifak etmişlerdir. Usûlün nafakasının vücûbiyetine dair aykırı bir görüş beyan edilmediği için de bu konuda icmâ oluşmuştur. ${ }^{25}$ Görüldüğü üzere usûle karş1 nafaka yükümlülüğü; Kitap, sünnet ve icmâ ile sabit olup durumu iyi olan her evladın yerine getirmesi zorunlu (farz) bir vazifedir.

\subsection{Ebeveyne Karşı Nafaka Sorumluluğunda Aranan Şartlar}

\subsubsection{Tarafların Ekonomik Durumu}

Anne ve babanın nafakasını karşılamak, bağlayıcılığı olan hukuki bir yükümlülüktür. Ancak kişinin anne, baba, dede ve nineden oluşan üst soyuna (usûl) karşı bu yükümlülüğü mutlak değildir. Bu sorumluluğun oluşabilmesi için belirli şartlar vardır.

Öncelikle usûlün nafaka alacaklısı olabilmesi için fakir olması gerekir. Buna göre dinen zengin durumda olan veya ihtiyacı olmayan ebeveyn nafaka talebinde bulunamayacağı gibi, bu durum çocuklar üzerinde hukuki bir yükümlülük oluşturmaz. ${ }^{26}$ Osmanlı'da muteber kabul edilen fetvâ mecmuâlarında yer alan fetvâ örnekleri de bu durumu somut bir şekilde ortaya koymaktadır. Söz konusu fetvâlarda, hali vakti yerinde ve ihtiyacı olmayan ebeveynin çocuklarından nafaka alamayacağı açık bir şekilde ifade edilmektedir. ${ }^{27}$

Osmanlı hukukunda kadı sicilleri adı verilen vesikalarda kayıt altına alınan mahkeme kayıtları da bu anlatıy desteklemektedir. Osmanlı toplumunda fakir ve muhtaç durumda olup çalışmaya gücü yetmeyen ebeveynler, evlatları ya da torunları tarafından kendilerine nafaka verilmesi için mahkemeye müracaat etmişlerdir. Örneğin İstanbul Bâb Mahkemesi (1833-1837 yıllarına ait), 390 numaralı mahkeme defterinde yer alan dava örneğinde bir kadın "ben zât-ı zevc olmayub alîle ve fakîre ve mu'sire ve oğlum mezbûr Ahmed Nazif mûsir olmakla" ifadesiyle kendisinin dul, hasta, fakir ve muhtaç, oğlunun da zengin olduğunu beyan ederek nafaka talebinde bulunmuş, bunun üzerine hâkim annenin ihtiyaçlarının karşılanması için oğlu üzerine günlük 80 akçe nafaka takdir edilmesine ve gerekirse bunun için onun adına borçlanabilmesine (istidâne) karar vermiștir. ${ }^{28} \mathrm{Bu}$ dava örneğinde anneye nafaka

24 Muhammed Revvas Kal'aci, el-Mevsû‘atü'l-fikhiyyetü'l-müyessere (Beyrut: Dârü’n-Nefâis, 2000), 2/1941.

25 Kâsânî, Bedâiu's-sanâi', 4/15.

26 Kudûrî, Ebü'l-Hüseyn, el-Muhtasar (Beyrut: Dâru'l-Kütübi'l-İlmiyye, 1997), 1/174; Burhâneddin Ali b. Ebî Bekr el-Mergînânî, el-Hidâye şerhu bidâyeti'l-Mübtedî (Beyrut: Dâru İhyâi't-Türâsi'l-Arabî, ts.), 2/292; Mevsilî, el-îhtiyâr, 4/10; Aynî, el-Binâye, 5/699.

27 Şeyhülislam Feyzullah Efendi, Fetâvâ-yı Feyziye (ìstanbul: Süleymaniye Kütüphanesi, Pertevniyal, 347), 117, 122; Çatalcalı Ali Efendi, Fetâvâ-yı Ali Efendi (İstanbul: Süleymaniye Kütüphanesi, Pertevniyal, 345), $1 / 110$.

28 Sariye Abay Bakırcan, İslam-Osmanl Hukukunda Nafaka: İstanbul Bab Mahkemesi Örneği (İstanbul: Marmara Üniversitesi, Sosyal Bilimler Enstitüsü, Yüksek Lisans Tezi, 2013), 57. 
takdir edilmesinin sebebi, onun fakir ve muhtaç olması sebebiyledir. Zira annenin kendisi zengin veya evli olup kocası zengin olsaydı nafaka alamazdı. Öyle ki Galata Mahkemesine ait 259 numaralı sicil defterinde (1724 yılına ait) yer alan örnekte bir kadın hasta ve muhtaç olduğunu, ihtiyaçlarını karşılayamadığını söyleyerek nafaka talebinde bulunmuş; ancak oğlu annesinin evli olduğunu, nafakasının kocası tarafından karşılandığını ve onun muhtaç olmayıp zengin olduğunu iddia ederek karşı çıkmıştır. Yapılan tetkik sonucu ve şahitlerin ifadeleriyle kadının zengin olduğu anlaşılınca hâkim nafaka takdir edilmesinin meşru olmadığına dair hüküm vermiştir. $^{29}$

İslam hukukunda usûlün nafaka alacaklısı olabilmesi için fakir olmasının tek başına yeterli olmadı̆̆ı, bunun için aynı zamanda kendi nafakalarını temin etme imkânından mahrum olmaları gerektiği hususunda farklı görüşler bulunmaktadır. Ancak Hanefîlerin de içinde bulunduğu çoğunluk, üstsoyun nafaka alabilmesi için fakir olmalarının tek başına yeterli olduğu kanaatindedirler. ${ }^{30}$ Serahsînnin (öl. 483/1090) de belirttiği üzere, normalde hiç kimse sağlıklı olan fakir bir yakınının nafakasını vermeye zorlanamaz; ancak anne ve baba ile dede bu kuraldan istisna edilmektedir. Çünkü usûlün nafakasının temin edilmemesi, birtakım sıkıntılara yol açar ki, bu durum İslam'ın temel öğretileriyle asla bağdaşmaz. Bu sebeple ebeveynler sağlıklı olsalar dahi çocuklar ya da torunlardan oluşan altsoy, onların karşılaşacakları yorgunluk, üzüntü ve sıkıntıları kaldırmak için nafaka ile sorumlu tutulmuş; hatta gerektiğinde yargı yoluyla bunun icra ve ifası için altsoyun zorlanabileceği ifade edilmiştir. $^{31}$

Alt soyun nafaka ile sorumlu olabilmesi için dinen zengin olması gerekir. Ancak bazı çalışmalarda Hanefîler'e göre usûlün nafakasından sorumlu olmak için zenginlik şartının aranmadığı iddia edilmektedir. ${ }^{32}$ Hanefî kaynaklarında bu iddiayı destekleyen ifadeler mevcuttur. Örneğin Kâsânînin (öl. 587/1191) ifadesine göre, fakir ve çalışan durumda olan çocuğun kazandı̆̆ı parası kendi azı̆̆ından fazlaysa, çocuk bu fazlalıktan babasının nafakasını karşılama hususunda zorlanabilir. ${ }^{33}$ Aynı şekilde İbn Nüceym (öl. 970/1563) fakir olan bir kişinin, sadece usûl ve fürû' ile eşinin nafakasından sorumlu olacağıyla ilgili bir bilgiyi aktarır. ${ }^{34}$ Ancak Hanefî literatürü dikkatlice incelediğinde bu görüşün mezhep içerisinde kabul görmediği anlaşılmaktadır. ${ }^{35}$ Çünkü Hanefîler'e göre alt soyun (fürû') ebeveynlerine karşı nafakayla yükümlü olabil-

29 Taylan Akyıldırım, 259 Numaralı Şeriyye Sicili Defterine Göre Galata (İstanbul: Mimar Sinan Üniversitesi, Sosyal Bilimler Enstitüsü, Yüksek Lisans Tezi, 2010), 283-284.

30 Serahsî, el-Mebsût, 5/228; Kâsânî, Bedâiu's-sanâit, 4/35; Ebû Zekeriya Muhyiddîn Yahya b. Şeref enNevevî, Ravzatü't-tâlibîn ve umdetü'l-müftîn, thk. Züheyr eş-Şâvîş (Beyrut: el-Mektebü'l-İslâmî, ts.), 9/84; İbn Kudâme el-Makdisî, el-Muğnî (Kahire, Mektebetü'l-Kahire, 1968), 8/215.

31 Serahsî, el-Mebsût, 5/228; Kâsânî, Bedâiu's-sanâi', 4/35.

32 Özlem Çelik, İslam Hukukun da Hısımlık Nafakası Mükellefiyetinde Din Farkı (Ankara: Ankara Üniversitesi, Sosyal Bilimler Enstitüsü, Yüksek Lisans Tezi, 2013), 23; Ateş, “Ergin Akrabaya Karşı Nafaka Yükümlülüğ̈̈”, 15.

33 Kâsânî, Bedâiu's-sanâi', 4/36.

34 İbn Nüceym, Bahrü'r-râik, 4/230.

35 İbn Âbidîn, Reddü'l-Muhtâr, 3/621-622. 
mesi için dinen zengin olmaları gerektiği, fakir olmaları durumunda ise sorumlu olmadıkları açıkça ifade edilmektedir. ${ }^{36}$ Nitekim Hanefî fakihlerinden Kâdıhân (öl. 592/1196), fakir durumda olan çocuk üzerine nafakanın vacip olmayacağını, ${ }^{37}$ Zeylâ̂̂ (öl. 743/1343) ise fakir olmanın acizlik anlamına geldiğini, böyle bir kişiye nafaka yüklenemeyeceğini, bu yüzden alt soy için zenginliğin şart koşulduğunu ifade etmektedir. ${ }^{38}$

Hanefî mezhebinde ebeveyne karşı nafaka sorumluluğunda zenginlik şartı aranır; ancak bunun ölçüsünün ne olacağı hususu ihtilaflıdır. Buradaki ihtilafın asıl sebebi, mûsir kelimesine yüklenen anlamla yakından alakalı olduğu için bu kavrama yüklenen anlamların tespit edilmesi gerekir. Çünkü klasik Hanefî kaynaklarında usûlün nafakası anlatılırken genellikle karşımıza çıkan ve bu konuda alt soyun sorumluluğunu belirleyen şey "mûsir" kavramıdır. ${ }^{39}$ Ebû Yûsufa (öl. 182/798) göre mûsir kavramıyla kastedilen zenginliğin ölçüsü nisaptır. Tabi burada kabul edilen nisabın zekât ya da fitreden hangisine göre takdir edileceği hususunda iki görüş bulunmaktadır. ${ }^{40}$ Ebû Yûsufun görüşünü benimseyen Kâdıhân mûsir kavramını "zekâtın vacip olacağı miktara ulaşacak kadar ailesinin nafakasından fazla mala sahip olan kişı" olarak tanımlarken ${ }^{41}$ Mergînânî (öl. 593/1197) fetvanın buna göre olduğunu söylemektedir. ${ }^{42}$ Mevsılî (öl. 683/1284) burada itibar edilen zenginliğin, kişinin zekât almasını haram kılacak mali bir güç ile eş değer olduğunu belirtirken İbn Nüceym de -tıpkı onun gibi- tercih edilen görüşün bu olduğunu ifade etmektedir. ${ }^{43}$ Ancak İmam Muhammed (öl. 189/805) burada nisab yerine kişinin çalışıp kazanmaya güç yetirebiliyor olmasını, yani imkânını dikkate almaktadır. Nitekim kendisi, nafakadaki zenginlik ölçüsünü kişinin aylık düzenli bir gelirinin olup olmamasına göre belirlemektedir. ${ }^{44}$ Kişi aylıkla çalışan ve düzenli bir geliri olan kimselerden ise, bu durumdaki zenginlik ölçüsü kişinin kendisinin ve ailesinin bir aylık nafakasından fazla mala sahip olmasını ifade ederken; esnaftan biri olması durumunda bu miktar kişinin bir günlük nafakasından kalan fazlalığa göre

36 Serahsî, el-Mebsût, 5/222; Semerkandî, Alâeddin, Tuhfetü'l-Fukahâ (Beyrut: Dâru'l-Kütübi'l-illmiyye, 1984), 2/168; Kâsânî, Bedâiu's-sanâi', 4/35; Kâdîhân, Ebü'l-Mehasin Fahreddin Hasan b. Mansur b. Mahmûd, Fetâvâ Kâdîhân fi mezhebil'-İmâmi'l-A'zam Ebî Hanîfete'n-Nu'mân, nşr. Salim Mustafa el-Bedrî (Beyrut: Dârü'l-Kütübi'l-ilmiyye, 2009), 1/388; Mevslî̂, el-îhtiyâr, 4/12; Zeylâ̂i, Tebyînül-hakâik, 3/64; Aynî, el-Binâye, 5/699; i̇bnü'l-Hümâm, Fethü'l-Kadîr, 4/423; Damâd, Mecmaü'l-enhur, 1/499; İbn Âbidîn, Reddü'l-Muhtâr, 3/621-622.

37 Kâdîhân, Fetâvâ Kâdîhân, 1/388.

38 Zeylâ̂̂, Tebyînül-hakâik, 3/64.

39 Burhâneddîn el-Buhârî, el-Muhîtu'l-Burhânî, 3/583; Kâsânî, Bedâiu's-sanâi', 4/35; Kâdîhân, Fetâvâ Kâdîhân, 1/388; Mergînânî, el-Hidâye, 2/293; Mevs11î, el-ihtiiyâr, 4/12; Zeylâ̂,, Tebyînül-hakâik, 3/64; İbn Nüceym, Bahrü'r-râik, 4/230; i̇bn Âbidîn, Reddü'l-Muhtâr, 3/621-622; Meydânî, el-Lübâb, 3/104.

40 Birinci görüşe göre mûsir, zekât nisabı kadar mala sahip olan ve zekât vermekle yükümlü olan kişi anlamında gelirken; diğer görüşe göre fitre nisabı kadar mala sahip olan ve zekât alması haram olan kişi manasına gelir.

${ }^{41}$ Kâdîhân, Fetâvâ Kâdîhân, 1/388.

42 Mergînânî, el-Hidâye, 2/293.

${ }_{43}$ Mevs1lî, el-ìhtiyâr, 4/12; İbn Nüceym, Bahrü'r-râik, 4/230.

${ }^{4}$ Burhâneddîn el-Buhârî, el-Muhîtu'l-Burhânî, 3/583; Kâsânî, Bedâiu's-sanâi', 4/35; Mergînânî, el-Hidâye, 2/293; Mevs1lî, el-ìhtiyâr, 4/12; Zeylâi, Tebyînül-hakâik, 3/64; i̇bn Nüceym, Bahrür-râik, 4/230; i̇bn Âbidîn, Reddü'l-Muhtâr, 3/621-622. 
takdir edilir. Görüldüğü üzere İmam Muhammed nafakada nisabı dikkate almamaktadır. Çünkü ona göre nafaka bir kul hakkıdır, kul haklarında ise nisaba değil, kişinin çalışıp kazanmaya güç yetirebilecek durumda olmasına itibar edilir. Her ne kadar İbn Nüceym (öl. 970/1563) bu görüşle amel edeni görmediğini ifade etse ${ }^{45}$ de, Hanefîlerden Alâüddîn es-Semerkandî (öl. 539/1144), İbnü'l-Hümâm (öl. 861/1457), Zeylâî (öl. 743/1343) ve İbn Âbidîn (öl. 1252/1836), İmam Muhammed'e nispet edilen bu görüşün daha uygun olduğunu düşünmektedir. ${ }^{46}$

Usûle karşı nafaka sorumluluğunda gerekli olan zenginliğin ölçüsünün ne olduğu hususunda farklı görüşler mevcut olsa da Hanefî mezhebine göre dinen zengin durumda olan çocuklar üst soyun nafakasını karşılamak zorundadır; ancak çocuklar ve torunlardan oluşan alt soy fakirse, bu durum nafaka yükümlülüğünü doğurmaz. Fetvâ mecmuâlarında yer alan örnekler de bunu desteklemektedir. Söz konusu fetvâlarda, dinen zengin sayılan alt soyun fakir ve muhtaç olan üst soyun nafakasından sorumlu olacağı, alt soyun fakir olması durumunda ise usûlün nafakasından sorumlu olmayacağı bariz bir şekilde ifade edilmektedir. ${ }^{47}$ Fetâvâ-yı Feyziye' de karşılaşllan bir fetvâda görüldüğü üzere, nafaka yükümlüsü olan alt soyun zenginliklerinin farklı olmasının bu sorumluluğa herhangi bir etkisi yoktur, yükümlü olan taraflar birlikte eşit bir şekilde sorumlu olurlar. ${ }^{48}$

Yukarıda görüldüğü üzere, alt soyun fakir olması usûle karşı nafaka yükümlülüğünü ortadan kaldırır. Ancak fakir ve muhtaç olan ebeveynin hasta ve yatalak olup herhangi bir kazanıcının olmaması farklı değerlendirilmektedir. Bu durumda kişinin dinen zengin olup olmadığına değil, çalışabiliyor olmasına bakılmaktadır. Hanefî mezhebinde zâhirü'r-rivâye olan görüşe göre, çocuğun geçimini sağlamaya çalıştığı bir ailesi varsa, böyle bir durumda fakir olan bir kişinin bakıma muhtaç olan babasını yanına alarak nafakasını paylaşması gerekir. Bu sebeple olay mahkemeye intikal ettiğinde hâkim kazâen çocuğu nafakaya zorlayabilir. Zikredilen rivayetlerde çocuğun nafakası kendisine ve ailesine yetecek kadar olsa da, böyle yapılmadığı takdirde babanın ölebileceği, buna karşın kişinin babasını yanına alıp nafakasını paylaşmak suretiyle bu durumun önüne geçileceği ve kimseye zarar vermeyeceği ifade edilmektedir. Buna karşın çocuğun tek başına yaşayıp kendi nafakasından başka bir şeyin olmaması durumunda, kişinin kazâen babasının nafakasından sorumlu olmadı̆̆ı; ancak zâhirü'r-rivâyeye göre diyâneten sorumlu olduğu zikredilmektedir. ${ }^{49}$

45 İbn Nüceym, Bahrü'r-râik, 4/230.

46 Semerkandî, Tuhfetü'l-Fukahâ, 2/168; Zeylâî, Tebyînül-hakâik, 3/64; İbnü'l-Hümâm, Fethü'l-Kadîr, 4/423; Haskefî, ed-Dürrü'l-muhtâr, 1/264; İbn Âbidîn, Reddü'l-Muhtâr, 3/621.

${ }^{47}$ Yeni Şehirli Abdullah Efendi, Behcetü'l-fetâvâ (İstanbul: Süleymaniye Kütüphanesi, Pertevniyal, 327), 123; Feyzullah Efendi, Fetâvâ-yı Feyziye (Pertevniyal, 347), 116, 121; Çatalcalı Ali Efendi, Fetâvâ-yı Ali Efendi (Pertevniyal, 345), 1/111.

48 “Zeyd-i fakirin oğulları Amr ve Bekir'den gayrı kimesnesi olmayıp Amr ve Bekir'den her biri mûsir olmakla Amr Bekir'e 'Zeyd'i beraber infak edelim' dedikde Bekir Amr'a mücerred 'Senin malın ziyade olmakla Zeyd'i sen müstakillen infak eyle' demeye kâdir olur mu? El-Cevâb: Olmaz." bk. Şeyhülislam Feyzullah Efendi, Fetâvâ-yı Feyziye (Pertevniyal, 347), 115. Bu görüş için bk. Kâdîhân, Fetâvâ Kâdîhân, 1/388.

49 Serahsî, el-Mebsût, 5/222, 228; Kâsânî, Bedâiu's-sanâit, 4/35-36; Kâdîhân, Fetâvâ Kâdîhân, 1/388; İbnü'lHümâm, Fethü'l-Kadîr, 4/418; İbn Nüceym, el-Bahru'r-raik, 4/223; İbn Âbidîn, Reddü'l-Muhtâr, 3/621-622. 
Türk Medeni Hukuku'na gelince, üst soyun nafaka alabilmesi için öncelikle kişinin çalışıp kazanma imkânından mahrum olması gerekir. Ebeveyne karşı nafaka sorumluluğunda ise, alt soy için zenginlik şartının arandığı söylenemez; ancak burada kişinin sorumlu olması için ödeme gücüne sahip olmasının yeterli olduğu ifade edilmektedir..$^{50}$

\subsubsection{Tarafların Farklı Dinden Olmaları}

Hanefîlerin de içinde bulunduğu çoğunluğa göre, usûl ve fürû arasındaki nafaka sorumluluğunda aynı dine mensup olma şartı aranmamaktadır. Bu yüzden, usûle karşı nafaka sorumluluğunda taraflardan birinin farklı dine mensup olması yükümlülüğü düşürmemektedir. Dinen zengin durumda olan Müslüman bir evlat, zimmî statüsündeki anne ve babasının nafakasını karşılamak zorunda olduğu gibi aynı şekilde zimmî olan bir çocuk da Müslüman olan üstsoyun nafakası ile sorumlu olur. ${ }^{51}$

Aslında genel kurala (kıyas) göre, din farklılığı nafaka hukukunun oluşmasına manidir. Ancak Ebû Hanîfe (öl. 150/767) bu meselede "Müslüman olan bir çocuk, zimmî olan anne ve babasının nafakasını karşılamak zorundadır." diyerek istihsan yoluyla anne ve babanın durumunu genel kuraldan istisna etmiştir. ${ }^{52}$ Nitekim Kur'an'-1 Kerim'de yer alan ilgili âyetler ve hadisler mutlak olarak zikredilmekte ve burada tarafların nafaka ile sorumlu olabilmesi için aynı dine mensup olmaları gerektiğine dair hiçbir bir kayıt yer almamaktadır. Öyle ki bu konuya delil teşkil eden ayetlerden birinde mutlak olarak anne ve babaya iyilik edilmesi gerektiği beyan edilirken, ${ }^{53}$ bir başka ayette ise dünyada iken farklı dine mensup olan ebeveynlere iyi davranılması gerektiğine işaret edilmektedir..$^{54}$

Usûl ve fürûun farklı dinden olmaları nafaka sorumluluğunu ortadan kaldırmaz, ancak Hanefî mezhebinde bu kuralın zimmî ile Müslümanlar arasında geçerli olduğu kabul edilmektedir. ${ }^{55}$ Bu sebeple, Müslüman veya zimmî olan bir kişi, düşman topraklarında (dârü'l-harb) yaşayan ve oranın vatandaşı olan (harbî) anne ve babasının nafakasını - emân (izin) alarak İslam diyarına gelseler bile- vermeye zorlanamaz. Zira nafaka hukuku, akrabalık bağını gözetmek ve onları kollamak için meşru kılınmıştır. Serahsînnin ifade ettiği üzere, harbî statüsünde olan bir kimsenin Müslüman olan kimseyle böyle bir bağın olmadı̆̆ına hükmedilmektedir. ${ }^{56}$ Ancak Hanefî fakihlerinden Kâsâni bu konuda farklı düşünerek bu yükümlülüğün vücub sebebinin cüz'iyyet olduğunu, taraflardan birinin müste'men olmasının nafaka sorumluluğunu ortadan kaldırmadı-

50 Akıntürk, Türk Medeni Hukuku Aile Hukuku, 462.

51 Serahsî, el-Mebsût, 5/228-229; Mergînânî, el-Hidâye, 2/292; Zeylâî, Tebyînül-hakâik, 3/63; Aynî, el-Binâye, 5/699; Molla Hüsrev, Dürerü'l-hükkâm, 1/420; İbn Nüceym, Bahrü'r-râik, 4/226; Haskefî, ed-Dürrü'l-muhtâr, 1/264; Damâd, Mecmaü'l-enhur, 1/502; İbn Âbidîn, Reddü'l-Muhtâr, 3/631; Meydânî, el-Lübâb, 3/104.

52 Serahsî, el-Mebsût, 5/226.

53 el-İsrâ, 17/23

54 "Eğer anne baban, hakkında bilgin olmayan bir şeyi bana ortak koşman için seni zorlarlarsa bu durumda onlara uyma, ama dünyada iken yine de onlara iyi davran". Bk. Lokman, 31/15.

55 Serahsî, el-Mebsût, 5/228-229; Mergînânî, el-Hidâye, 2/292; Zeylâî, Tebyîül-hakâik, 3/63; Aynî, el-Binâye, 5/699; Molla Hüsrev, Dürerü'l-hükkâm, 1/420; İbn Nüceym, Bahrü'r-râik, 4/226; Haskefî, ed-Dürrü'l-muhtâr, 1/264; Damâd, Mecmaü'l-enhur, 1/502; İbn Âbidîn, Reddü'l-Muhtâr, 3/631; Meydânî, el-Lübâb, 3/104.

56 Serahsî, el-Mebsût, 5/228-229; Molla Hüsrev, Dürerï̈l-hükkâm, 1/420; Damâd, Mecmaü’l-enhur, 1/502. 
ğını, bu yüzden de alt soyun müste'men olan usûlün nafakasını ödeyeceğini ifade etmektedir. $^{57}$

Görüldüğü üzere, usûl ve fürû arasındaki din farkı nafaka yükümlülüğe engel teşkil etmemektedir. Çünkü buradaki temel kural, yakınlık ve cüziyyettir. ${ }^{58}$ Yani usûlün nafaka hakkı, varis-mûris ilişkisinden değil asıl-cüz ilişkisinden kaynaklanmaktadır. Dolayısıyla buradaki yükümlülüğün vücub sebebi, irsiyet değil cüziyettir; yani tarafların birbirlerinin parçası olmalarıdır. Usûl ve fürû arasındaki bu güçlü nesep bağı sebebiyle din farkının bu ilişkiye herhangi bir etkisinin olmadığı fikri benimsenmiştir. ${ }^{59}$ Osmanlı dönemi fetvâ mecmuâlarında yer alan şu örnekler de bu durumu açık bir şekilde ortaya koymaktadır:

“Hind-i nasrâniye fakire ve mu'sire olup mûsirler olan oğulları Zeyd-i müslim ve Amr-ı nasrânî ile mûsire olan kızı Zeyneb-i nasrâniyeden gayrı kimesnesi olmasa Hind'in nafakası mezbûrların üzerine ne vechile lâzıme olur? ElCevâb: Beraber."

"Fakir olan Zeyd-i zimmînin nafakası mûsir olan oğlu Amr-1 müslim üzerine lâzıme olur mu? El-Cevâb: Olur." ${ }^{61}$

"Zeyd-i Müslim fakir ve muhtac olub mûsir olan oğulları Amr ve Bekir-i zimmîlerden gayrı kimesnesi olmasa Zeyd'in nafakası Amr ve Bekir üzerine lâzıme olur mu? El-Cevâb: Olur." ${ }^{2}$

Zikredilen bu fetvâların ilk ikisinde fakir ve Müslüman olmayan zimmî bir anne ile babanın nafakasının zimmî olanlarla birlikte Müslüman olan çocuklarına, diğer fetvada ise fakir ve muhtaç durumda olan Müslüman bir babanın nafakasının zimmî statüsündeki oğullarına ait olacağı ifade edilmektedir. Bu fetvâların yanı sıra, Osmanlı dönemi mahkeme kararlarının kayıt altına alındığı şer’iyye sicillerinde yer alan dava örnekleri usûlün nafakasında din farkının yükümlülüğe mâni olmadığını göstermektedir. Nitekim karşılaşılan davalardan birinde, gayrimüslim ve zimmî olan bir baba kendisinin hasta ve çalışmaktan aciz olduğunu beyan ederek nafaka talebi için mahkemeye başvurmuş, bunun üzerine hâkim de biri Müslüman diğeri gayrimüslim olan iki çocuk üzerine nafaka takdir etmiştir. ${ }^{63}$ Bir başka dava örneğinde ise, sonradan Müslüman olan bir baba hasta ve çalışmaktan aciz olduğunu ifade ederek zimmî olan oğlundan nafaka almak için mahkemeye başvurmuş, sonrasında da hâkim günlük 6 akçe nafakaya hükmederek bu kişiye nafaka hücceti vermiştir. Ancak baba aradan geçen süre zarfında ödenmeyen nafakanın bir kısmını tahsil edebilmek için tekrar mahkemeye müracaat etmiş, bunun üzerine baba ile oğul mahkemede belirli bir fiyat üzerinde sulh etmiş, sonrasında da

57 Kâsânî, Bedâiu's-sanâi', 4/36-37.

58 Serahsî, el-Mebsût, 5/222; Mergînânî, el-Hidâye, 2/292-293; Babertî, el-inâye, 4/418; Aynî, el-Binâye, 5/703; İbn Nüceym, Bahrü'r-râik, 4/224; Damâd, Mecmaü'l-enhur, 1/502; Meydânî, el-Lübâb, 3/105.

59 Kudûrî, el-Muhtasar, 1/174; Serahsî, el-Mebsût, 5/226; Mevsılî, el-ìhtiyâr, 4/11; Aynî, el-Binâye, 5/699; İbn Nüceym, Bahrü'r-râik, 4/226; Haskefî, ed-Dürrü'l-muhtâr, 1/265

60 Çatalcalı Ali Efendi, Fetâvâ-yı Ali Efendi (Pertevniyal, 345), 112.

${ }^{61}$ Yeni şehirli Abdullah Efendi, Behcetü'l-fetâvâ (Pertevniyal, 327), 123.

62 Çatalcalı Ali Efendi, Fetâvâ-yı Ali Efendi (Pertevniyal, 345), 111.

63 Nevzat Erkan, Osmanlı Üsküdar'inda Toplumsal Hayat (İstanbul: Üsküdar Belediyesi, 2015), 145. 
nafaka yükümlüsü olan zimmî oğul bir başkasını kefil göstererek günlük nafakayı ödeyeceğini taahhüt etmiştir. ${ }^{64}$

\subsubsection{Nafaka Yükümlüsü Olan Çocuğun Gâip Olması}

Alt soyun gâip ${ }^{65}$ olması durumunda usûlün nafakasının nasıl karşılanacağı, Hanefî mezhebinde detaylıca ele alınmıştır. Aslında mezhepteki temel kurala göre, hâkim gâipte olan bir kişinin malından başkasının nafakasına dair hüküm veremez; ancak anne ve baba ile eşin durumu bu kuraldan istisna edilmiştir. ${ }^{66}$ Buna göre nafaka yükümlüsü ortada yok veya kayıp ise, hâkim bu kişinin malından anne ve babanın nafakasının karşılanmasına hükmedebilir. Çünkü anne ve baba nafaka alma hususunda ittifak edilen kimselerdendir. Bununla birlikte anne ya da baba mahkeme kararı olmaksızın çocuklarına ait yanlarındaki mallardan bu haklarını alabilirler. Serahsînnin de ifade ettiği üzere bu meselede hâkime düşen görev, nafaka alacaklısı olan bu kişilerin haklarına ulaşmalarına yardımcı olmaktır. Dolayısıyla usûlün nafakasına dair hüküm verilebilmesi için alt soyun gâipte olup olmamasının bir önemi yoktur.

Konuyla ilgili tartışılan diğer bir husus, usûlün gâip olan çocuğuna ait bir malı satıp satamayacağı meselesidir. Nafaka alacaklısı olan kişilerden birisi, kayıp durumda olan kişiye ait bir malı satarsa, normalde bu satış iptal edilir. Ancak muhtaç durumda olan nafaka alacaklısı baba ise, onun çocuğu adına satış yapabileceği ve istihsana göre bu satışın câiz olacağı ifade edilir. Ancak bu hüküm, menkul mallar hakkında geçerli olduğu için baba çocuğuna ait taşınmaz (akar) bir malı satamaz. Zikredilen bu görüş Ebû Hanîfe'ye aittir. Ebû Yûsuf ile İmam Muhammed ise, nafaka hususunda babanın gâipte olan çocuğuna ait bir malı satamayacağı görüşünü benimsemektedir. Çünkü onlara göre çocuk, buluğ çağına ulaşınca babanın velayet hakkı sona ermekte ve mal satımı konusunda usûlün başkalarından bir farkı kalmamaktadır. Çocuğa ait olan bir malı başkası nasıl satamıyorsa, baba da aynı şekilde satamaz. Kişi nafaka sebebiyle babasına karşı borçlu olsa da söz konusu yükümlülüğün diğerlerinden öncellikli bir borç sayılmayacağı, bu yüzden de babanın çocuğuna ait olan bir malı satamayacağı söylenmektedir. İmâmeyn'in tercih ettiği bu görüş mezhepteki temel kuralı yansitır. Ancak Ebû Hanîfe, babanın gâipte olan çocuğuna ait menkul malları istihsanen satabileceği görüşünü benimsemiştir. Çünkü ona göre, çocuğun buluğ çağına ulaşmasıyla velayet hakkı sona erse de velayetin bazı izleri devam etmektedir. Ebû Hanîfe bu gerekçeye dayanarak bir babanın nafakasını karşılamak için gâipte olan çocuğuna ait menkul bir malı satıp bu paradan kendi nafakasına düşen miktarı alabileceğini söylemektedir. ${ }^{67}$

64 Erkan, Osmanlı Üsküdar'inda Toplumsal Hayat, 145.

65 Gâip kelimesi, nerede olduğu bilinmeyen ve kendisinden uzun süre haber alınamayan kişiyi ifade eder.

66 Kudûrî, el-Muhtasar, 1/174; Serahsî, el-Mebsût, 5/225; Mergînânî, el-Hidâye, 2/294; Zeylâî, Tebyînül-hakâik, 3/59-60; Babertî, el-İnâye,4 /423-424; Aynî, el-Binâye, 5/708-710; İbn Âbidîn, Reddü'l-Muhtâr, 3/622, 632633; Meydânî, el-Lübâb, 3/108.

67 Kudûrî, el-Muhtasar, 1/174; Serahsî, el-Mebsût, 5/225-226; Mergînânî, el-Hidâye, 2/294; Mevsılî, el-İhtiyâr, 4/13; Zeylâî, Tebyînül-hakâik, 3/64-65; Babertî, el-inâye, 4/423; Aynî, el-Binâye, 5/709; Molla Hüsrev, Dürerü'l-hükkâm, 1/420; Damâd, Mecmaü'l-enhur, 1/502-503; İbn Âbidîn, Reddü'l-Muhtâr, 3/631; Meydânî, elLübâb, 3/108. 
Ancak bu konuda annenin ve diğer yakınların durumu, babanın durumundan farklıdır. Alacaklı olmaları açısından aralarında bir fark olmasa da anne nafakasını temin edebilmek için çocuğuna ait bir eşyayı satamaz. ${ }^{68}$ Çünkü Serahsînin de ifade ettiği üzere çocuğun küçüklüğünde dahi annenin böyle bir tasarruf yetkisi yoktur. Buluğdan önce mevcut olmayan bu yetkinin erginlikten sonra da olmayacağı düşüncesiyle, annelerin çocuğa ait menkul malları satmasının câiz olmadığı ifade edilmiştir. ${ }^{69}$

Tartışılan diğer bir mesele de gâip olan çocuğa ait bir malın bulunmadığı durumda anne ve babanın nafakasının nasıl karşılanacağı hususudur. Osmanlı'da muteber kabul edilen fetvâ mecmuâları ile şer'iyye sicillerinde yer alan örnekler, bu konuda nasıl bir yol izlendiğini açıkça göstermektedir. Konuyla ilgili Netîcetü'l-fetâvâ'da yer alan iki fetvâ örneğinde, çocukların nafaka bırakmadan uzak bir yere gitmeleri durumunda fakir ve muhtaç durumdaki anne ya da babanın hâkime başvurmak suretiyle günlük kendilerine belirli bir miktar nafaka takdir ettirdikleri, bu hususta istidâneye dair izin aldıkları ve çocukların kendileri adına yapılan bu borçların döndükleri zaman onlardan alınacağı ifade edilmektedir. ${ }^{70}$ Osmanlı şer’iyye sicillerinde yer alan dava örnekleri de bu durumu teyit etmektedir. Nitekim Eyüp Mahkemesi 90 numaralı sicil kaydında yer alan bir dava örneğinde, baba kendisinin yaşlı ve hastalığa meyyal bir bünyeye sahip olup çalışmaya gücünün yetmediğini, büyük oğlunun ise gâipte olduğunu söyleyerek nafaka talebinde bulunmuş; bunun üzerine hâkim babanın nafakasının karşılanması için oğlu üzerine günlük 28 akçe nafaka takdir edilmesine ve babanın ihtiyaç halinde çocuk adına borçlanabileceğine (istidâne) dair karar vermiştir. ${ }^{71}$ Zikredilen bu örnekler, nafaka yükümlüsü olan çocukların geride bir şey bırakmadan kaybolmaları durumunda usûlün nafakasını karşılayacak mekanizmaların devreye sokulduğunu göstermektedir. Öyle ki, böyle bir durumda anne ya da babanın ihtiyaç halinde çocuğu adına borçlanarak bir müddet nafakasını sağlayabileceği ifade edilmektedir. Anlatılan bu durum Osmanlı hukukunda mahkeme tarafından tanzim edilen nafaka hüccetlerinin sonunda açık bir şekilde görülmektedir. ${ }^{72}$ Söz konusu hüccetlerin sonunda "meblağ-ı mezkûrı harc ve sarfa ve lede'l-hâce istidâneye ve vakt-i zaferde merkūm ..... üzerine rücû'a izin verilip" biçiminde yer alan ifadeler, usûlün nafaka için yaptığı harcamaların ve bu sebeple ortaya çıkan borçların alt soy tarafından ödeneceğini ve onların nafakalarının hukuk tarafından korunduğunu somut bir şekilde ortaya koymaktadır. ${ }^{73}$

68 Serahsî, el-Mebsût, 5/225-226; Zeylâî, Tebyînül-hakâik, 3/65; Molla Hüsrev, Dürerü'l-hükkâm, 1/421; Damâd, Mecmaü'l-enhur, 1/503; İbn Âbidîn, Reddü'l-Muhtâr, 3/631.

69 Serahsî, el-Mebsût, 5/225-226.

70 Dürrizâde Mehmed Ârif Efendi, Netîcetü'l-fetâvâ maa'n-nukûl (İstanbul: Süleymaniye Kütüphanesi, Pertevniyal, 354), 105.

71 Eyüb Mahkemesi 90 Numaralı Sicil (1090-1091 /1679-1680), haz. Fuat Recep vd. (İstanbul: İSAM Yayınlar1, 2011), 31/517.

72 Nevzat Erkan, “Arşiv ve Mahkeme Kayıtlarına Göre Osmanlı Payitahtında Yaşlı Olmak (16-18. Yüzyıllar)”, Diyanet İlmi Dergi 56/1 (Mart 2020), 139.

73 Ayrıntılı bilgi için bk. Eyüb Mahkemesi 37 Numaralı Sicil (1047/ 1637-1638), 25/75; İstanbul Mahkemesi 10 Numaralı Sicil (1072-1073 /1661-1663), 51/885; Bab Mahkemesi 11 Numaral Sicil (1081/ 1670-1671), 53/84; Rumeli 


\subsection{4. Çocuklara Ait Malın Ebeveyn Tarafından Kullanımı}

Görüldüğü üzere usûle karşı nafaka sorumluluğu, Hanefî mezhebinde hâkimin hükmüne ihtiyaç duymadan sabit olan bir haktır. Bu sebeple, ebeveynler mahkeme kararı olmadan nafakalarını çocuklarından talep edebilir ve gerektiğinde onların mallarından ihtiyaçları kadarını alabilirler. ${ }^{74}$ Çünkü usûlün nafaka hakkını belirleyen asıl-cüz ilişkisi, anne ve babaya çocuklarının malından yararlanma hakkı verir. Ancak usûle tanınan bu tasarruf yetkisi, mutlak bir hak olmaktan çok ihtiyaçla sinırlidır.

Yukarıda ifade edildiği üzere, usûlün nafaka hakkı mahkeme kararı olmadan kendiliğinden doğan bir haktır. Bu sebeple, anne ve babanın yanında çocuğa ait bir mal bulunursa, ebeveynler -mahkeme kararı olmadan- nafakalarını bu maldan karşılayabilirler. Onların bu eylemi caiz olduğu için de daha sonra bu malları tazmin etmeleri gerekmez. ${ }^{75}$ Çünkü anne ve baba, hakkı olan bu miktarı çocuğuna ait yanındaki herhangi bir maldan alabilir ve bunda hiçbir sakınca görülmemektedir. Zira Hanefî mezhebine ait pek çok kaynakta ifade edildiği üzere, alacaklı olan kişi, kendi alacağı türden bir malı bulursa, bu maldan kendi hakkını alabilir. Ancak çocuğa ait olan mal başkasının elinde ise, bu kişi mahkeme kararı olmadan anne ve babanın nafakasını veremez; aksi halde tazminatla yükümlü tutulur. ${ }^{76}$

\subsection{Ebeveyn Nafakasının ölçüsü}

Nafaka kelimesi, insanın hayatını sürdürebilmesi için gerekli olan şeylerin tümünü içine alsa da kapsamına nelerin dâhil edilip edilmeyeceği hususunda farklı görüşler mevcuttur. Kaynaklara bakıldığında nafakanın tespitinde "ihtiyac"ın dikkate alındığı ve burada zikredilen şeylerin daha ziyade zarûrî ihtiyaçlar olduğu görülmektedir. Nitekim usûle karşı nafaka sorumluluğunda genellikle ebeveynin gıda, giyim, barınma ve bunun için gereken temel ev eşyaları gibi ihtiyaçları zikredilmektedir. ${ }^{77}$ Normal şartlarda hizmetçi ve bakıcı masrafları buraya dâhil değildir; ancak hastalık veya yaşlılık gibi sebeplerden dolayı bakıma

Sadâreti Mahkemesi 106 Numaralı Sicil (1067-1069/1656-1658), 2019, 50/460; Eyüb Mahkemesi (Havass-ı Refia) 90 Numaralı Sicil (1090-1091/1679-1680), 31/517.

74 Kudûrî, el-Muhtasar, 1/174; Serahsî, el-Mebsût, 5/225-226; Kâsânî, Bedâiu's-sanâi', 4/37; Mergînânî, elHidâye, 2/294; Zeylâî, Tebyînül-hakâik, 3/65; Babertî, el-İnâye, 4/424; Aynî, el-Binâye, 5/710; İbn Nüceym, Bahrü'r-râik, 4/233; Haskefî, ed-Dürrü'l-muhtâr, 1/266; Damâd, Mecmaü'l-enhur, 1/503-504; İbn Âbidîn, Reddü'l-Muhtâr, 3/627, 632-633; Meydânî, el-Lübâb, 3/108.

75 Kudûrî, el-Muhtasar, 1/174; Serahsî, el-Mebsût, 5/225; Kâsânî, Bedâiu's-sanâi,, 4/37; Mergînânî, el-Hidâye, 2/294; Zeylâî, Tebyîül-hakâik, 3/65; Babertî, el-İnâye, 4/424; Aynî, el-Binâye, 5/710; İbn Nüceym, Bahrü'r-râik, 4/233; Damâd, Mecmaü'l-enhur, 1/503; İbn Âbidîn, Reddü'l-Muhtâr, 3/627, 632-633; Meydânî, el-Lübâb, $3 / 108$.

76 Serahsî, el-Mebsût, 5/225; Mevsilî, el-İhtiyâr, 4/13; Zeylâî, Tebyînül-hakâik, 3/65; Haskefî, ed-Dürrü'lmuhtâr, 1/266; Molla Hüsrev, Dürerü'l-hükkâm, 1/420-421; İbn Nüceym, Bahrü'r-râik, 4/233; İbn Âbidîn, Reddü'l-Muhtâr, 3/622, 632-633.

77 Kâsânî, Bedâiu's-sanâit, 4/25, 38; Zeylâî, Tebyînül-hakâik, 3/50; Babertî, el-İnâye, 4/378; Aynî, el-Binâye, 5/659; İbnü'l-Hümâm, Fethü'l-kadîr, 4/378; İbn Nüceym, Bahrü'r-râik, 4/188, İbn Nüceym, en-Nehrü'l-fâik, 2/504-505; Damâd, Mecmaü'l-enhur, 1/484; Haskefî, ed-Dürrü'l-muhtâr, 1/257; İbn Âbidîn, Reddü'l-Muhtâr, 3/571, 628-629; Meydânî, el-Lübâb, 3/91. 
muhtaç olan kişilerin bakıcı ve hizmetçi masrafları da nafaka kapsamına dâhil edilebilmektedir. ${ }^{78}$

Nafaka sorumluluğunda asgari ölçüyü ifade etmek üzere karşımıza genellikle "kifâyet", "kadr-i kifâye" ya da "kadr-i ma'ruf” kavramları çıkmaktadır. ${ }^{79}$ Nitekim fetvâ mecmualarında yer alan örneklerde anne ya da babanın mahkemeye başvurmak suretiyle çocukları için kendilerine günlük belirli bir miktar nafaka takdir ettirdikleri ve izinsiz bir şekilde evladının malından bir miktar alabileceği ifade edilmektedir. ${ }^{80}$ $\mathrm{Bu}$ örneklerde nafakanın miktarı belirtilirken "kadr-i ma'ruf” terimi kullanılsa da buradaki miktarın belirli bir sınırı yoktur. Terimin kendisinden anlaşılacağı üzere buradaki ölçüyü belirleyen şey, insanların yaşadıkları zaman ve mekânın örf ile âdetidir. Çünkü ihtiyaçlar, içinde bulunulan zamana ve mekâna göre değişkenlik gösterebilir. Nitekim Hanefîlerin de içinde bulunduğu çoğunluk, nafaka konusunda her iki tarafın durumuna bakılması gerektiğini, zaman, mekân ve ahvalin değişmesiyle nafaka miktarının da değişebileceğini ifade etmişlerdir. ${ }^{81}$ Zikredilen sebeplerden dolayı nafakanın belirli bir miktar ile sınırlandırılması mümkün değildir.

Her ne kadar "kadr-i ma'ruf" teriminin net bir sınırı olmasa da bu kavram kişinin günlük ihtiyaçlarını karşılamasına yetecek bir miktar ile eş değer olup zamanın ekonomik şartlarına göre değişkenlik arz etmektedir. Osmanlı dönemi şer'iyye sicillerinde yer alan nafaka davaları da bu durumu açı bir şekilde teyit etmektedir. Örneğin 1637-1638 yıllarındaki nafaka davalarında "kadr-i kifâye" ya da "kadr-i ma'ruf" olarak takdir edilen günlük nafaka miktarı 3 akçe iken, 1661-1663 arasında 5 akçe, 1670-1671 yıllarında 6 akçe ve 1679-1680 yıllarındaki dava örneklerinde ise 8 akçe olarak belirlenmiștir. ${ }^{82}$

Kaynaklarda zikredilen ihtiyaçlar daha ziyade dönemin örf ve âdeti ile ekonomik şartlarını yansıtmaktadır. Bu yüzden, nafakanın kapsamı belirlenirken öncelikle örf ve âdet ile dönemin koşullarına bakılması ve bu hususların dikkate alınması gerekir. Örneğin bugünün şartlarında sadece bir evin alınarak teslim edilmesi nafaka alacaklısı olan kişilerin barınma ihtiyacının karşılanması için yeterli değildir. Günümüzün şartlarını dikkate alacak olursak, evde kullanılan temel eşyalar ile elektrik, su ve ısınma

78 Kâsânî, Bedâiu's-sanâi', 4/38; Mevs1lî, el-ïhtiyâr, 4/12; Zeylâî, Tebyînül-hakâik, 3/64; İbn Nüceym, Bahrü'rrâik, 4/224; İbn Âbidîn, Reddü'l-Muhtâr, 3/628-629.

79 Serahsî, el-Mebsût, 5/182; Burhâneddîn el-Buhârî, el-Muhîtu'l-Burhânî, 3/528; Kâsânî, Bedâiu's-sanâi', 4/38; Mergînânî, el-Hidâye, 2/294; Babertî, el-İnâye, 4/425; Aynî, el-Binâye, 5/711; İbn Nüceym, Bahrü'r-râik, 4/233; İbn Abidin, Reddü'l-Muhtâr, 3/633; Meydânî, el-Lübâb, 3/109.

80 Çatalcalı Ali Efendi, Fetâvâ-yı Ali Efendi (Pertevniyal, 345), 110-111; Dürrizâde Mehmed Ârif Efendi, Netîcetü'l-fetâvâ (Pertevniyal, 354), 105-106

81 Serahsî, el-Mebsût, 5/182; Burhâneddîn el-Buhârî, el-Muhîtu'l-Burhânî, 3/528; Babertî, el-İnâye, 4/382; Aynî, el-Binâye, 5/665; İbnü'l-Hümâm, Fethü'l-kadîr, 4/382-383; İbn Nüceym, Bahrü’r-râik, 4/190.

82 Eyüb Mahkemesi 37 Numaralı Sicil (1047/ 1637-1638), haz. Salih Kahriman, vd. (İstanbul: İSAM Yayınları, 2011), 25/75; İstanbul Mahkemesi 10 Numaralı Sicil (1072-1073 /1661-1663), ed. Coşkun Y1lmaz (İstanbul: Kültür AŞ. Yayınları, 2019), 51/885; Bab Mahkemesi 11 Numaralı Sicil (1081/ 1670-1671), ed. Coşkun Yılmaz (İstanbul: Kültür AŞ. Yayınları, 2019), 53/84; Rumeli Sadâreti Mahkemesi 106 Numaralı Sicil (1067-1069/ 16561658), ed. Coşkun Yılmaz (İstanbul: Kültür AŞ. Yayınları, 2019), 50/460; Eyüb Mahkemesi (Havass-ı Refia) 90 Numaralı Sicil (1090-1091/ 1679-1680), haz. Fuat Recep vd. (İstanbul: ISAM Yayınları, 2011), 31/517 
gibi giderlerin de barınma masrafları kapsamında nafakaya dâhil edilmesi gerekir. Dolayısıyla buradaki asıl maksat, usûlün normal bir şekilde hayatını sürdürebilmesi için gerekli olan ihtiyaçlarının karşılanmasıdır. Bu durum, ihtiyaç kapsamına girmeyen lüks eşyaların nafaka kapsamına dâhil edilmeyeceğini açık bir şekilde göstermektedir.

Nafakanın miktar ve kapsamının tespitinde kişilerin ekonomik durumları büyük önem arz etmektedir. Herhangi bir ihtiyacını karşılayamayan kimse ile bazı ihtiyaçlarını karşılayabilecek durumda olan kişilerin aynı kapsamda değerlendirilmesi mümkün olmadığı gibi zenginlik durumları farklı olan kişilerin sorumluluklarının da aynı olması düşünülemez. Nitekim Kur'an-1 Kerîm'de maddi imkânı geniş olan kişilerin nafakayı imkânlarına göre vereceği, imkânı kısıtlı olan kişilerin Allah'ın kendisine verdiği şeylerden ödemesi gerektiği ve Allah'ın bir kimseyi ancak verdiği imkânlar ölçüsünde sorumlu tutacağ ifade edilmektedir ${ }^{83} \mathrm{Her}$ ne kadar bu âyet eş ve çocukların nafakasıyla ilgili olsa da kişilerin özellikle maddi imkânları ölçüsünde sorumlu olacağına dair genel bir ilkeyi ortaya koymaktadır. Bu sebeple nafakanın miktarı tespit edilirken kişilerin ekonomik durumlarının dikkate alınması gerekmektedir.

Nafakanın kapsamı, Türk Medeni Hukuku'nda da kişilerin durumlarına göre belirlenmektedir. Nitekim Türk Medeni Kanunu'nun 365. maddesinde yer alan ifadeler açıkça bunu göstermektedir. Bu maddede açılandığı üzere, nafaka davası muhtaç olan kişinin geçinmesi için gereken ve yükümlü olan kişinin mâlî gücüne uygun bir yardım isteminden ibarettir. ${ }^{84}$ Buna göre, ebeveyne ait lüks ve gereksiz harcamalar nafakaya dâhil edilemez. Çünkü buradaki ölçü, kişinin geçinebilmesine yetecek bir miktardır. Nafaka miktarı, altsoyun yoksulluğa ve sıkıntıya düşmesine yola açacak şekilde de olamaz. Zira bu maddenin ikinci kısmında ifade edildiği gibi, nafaka miktarı yükümlü tarafin ekonomik ve mali durumuna uygun olarak takdir edilmelidir. Bununla birlikte mahkemenin takdir ettiği nafakanın miktarı gelecek yıllarda tarafların sosyal ve ekonomik durumlarına yeniden düzenlenebilir. Nitekim Türk Medeni Kanunu'nun 176. maddesinde ifade edildiği üzere, tarafların malî durumlarının değişmesi veya hakkaniyetin gerektirdiği hâllerde nafakanın artırılması veya azaltılmasına yönelik karar verilebilir. ${ }^{85}$

\subsection{Ebeveyne Karşı Nafaka Sorumluluğunda Öncelik Sırası}

Hanefîlere göre usûlün nafakasında cüz'iyyet vasfi, sıralamada ise yakınlık derecesi dikkate alınmaktadır. ${ }^{86} \mathrm{Bu}$ yüzden daha yakındaki fürû' var iken uzakta olan kişi nafaka ile yükümlü tutulamaz. Buna göre, yükümlülük şartlarını taşıyan evladın olduğu bir yerde torunun ya da usûlün nafaka ile sorumlu tutulması düşünülemez.

83 "Zengin olanlar, nafakayı imkânlarına göre versin. Rızkı ancak kendisine yetecek durumda olanlar da Allah'ın kendisine verdiğinden versin. Zira Allah, hiç kimseyi verdiği imkândan fazlasıyla yükümlü tutmaz." Bk. et-Talâk 65/7.

84 TMK, "Madde 365".

85 TMK, "Madde 176".

86 Kâsânî, Bedâiu's-sanâi', 4/35-37; Zeylâi, Tebyinül-hakâik, 3/64; i̇bnü'l-Hümâm, Fethü'l-kadîr, 4/418; Molla Hüsrev, Dürerü'l-hükkâm, 1/419; i̇bn Nüceym, Bahrü'r-râik, 4/225; ỉbn Âbidîn, Reddü'l-Muhtâr, 3/623-624. 
Çünkü anne ve babanın nafakasını sağlama konusunda çocuğa hiçbir kimse ortak olmaz. Bu sebeple ebeveynin nafakasıyla kendilerinin usûlü değil, çocukları yükümlü olur. $^{87}$

Ekonomik durumu yerinde olan çocuklar fakir ve muhtaç durumda olan ebeveynlerinin nafakasından sorumludur, ancak erkek ve kız çocukların ebeveynlerine karşı bu sorumluluğunda cinsiyet farkının nafaka sorumluluğuna bir tesirinin olup olmadığına dair farklı görüşler bulunmaktadır. Hanefî mezhebinde çocukların mirastaki paylarına göre sorumlu olacağını ifade eden bir görüş mevcut olmakla birlikte sahih olan görüşe göre cinsiyet farkının bir önemi yoktur, buradaki temel kural yakınlık ve cüz'iyyettir. Yani bu kişiler arasındaki nafaka hukuku, varis-mûris ilişkisinden değil asıl-cüz ilişkisinden kaynaklanmaktadır. Cinsiyet farkının bu ilişkiye herhangi etkisi olmadığı için de erkek ve kız çocuklar usûlün nafakasından eşit bir şekilde sorumlu olurlar. ${ }^{88}$ Çünkü erkek ve kız çocukları anne ve babanın birer parçası (cüz) olması hasebiyle eşit konumdadırlar. Tercih edilen bu görüş, uygulamada Hanefî mezhebini esas alan Osmanlı hukukunda da aynen tatbik edilmiştir. Nitekim Osmanlı Şeyhülislamlarından Çatalcalı Ali Efendi'nin (öl. 1103/1692) fetvâlarının bir araya getirildiği Fetâvây-ı Ali Efendi adlı eserdeki şu örnek bu durumu teyit eder niteliktedir:

"Hind-i fakirenin nafakası mûsirler olan oğlu Amr ile kızları Zeyneb ve Hatice üzerlerine ne vechile lâzıme olur? El-Cevâb: Cümlesinden beraber lâzıme olur." ${ }^{9}$

Yukarıdaki fetvâ örneğinde görüldüğü üzere, dinen zengin olarak kabul edilen erkek ve kız çocukları, anne ve babalarının nafakalarından birlikte ve eşit oranda sorumlu olurlar. Söz konusu durum, nafaka yükümlülügüüde Hanefî mezhebinin cüz'iyyet vasfını öne çıkardığını ve burada cinsiyet farkının önemli olmadığını göstermektedir. Anne ve babanın çocukları üzerindeki emekleri ve hakları dikkate alındığında Hanefîlerin bu yaklaşımının isabetli olduğunu söylemek mümkündür.

Türk Medeni Hukuku'nda ise usûle karşı nafaka sorumluluğunda mirasçılıktaki sıra dikkate alınır. Türk Medeni Kanunu'nun 365. maddesinde ifade edildiği üzere, nafaka davası mirasçılıktaki sıra göz önünde tutularak açılır. ${ }^{90}$ Buna göre üstsoyun nafakasında evlatlıklar da dâhil olmak üzere öncelikle kişinin çocukları sorumludur; çocukları yoksa veya yükümlülük şartlarını taşımıyorsa, bu durumda sorumluluk mirastaki sıraya göre altsoydaki diğer yakınlara (torun vb.) onlar da yoksa civar hısımlara (anne, baba ve kardeş gibi) geçer. ${ }^{91}$

87 Serahsî, el-Mebsût, 5/228; Kudûrî, el-Muhtasar, 1/174; Mergînânî, el-Hidâye, 2/292; İbn Âbidîn, Reddü'lMuhtâr, 3/623-624.

88 Serahsî, el-Mebsût, 5/222; Burhâneddîn el-Buhârî, el-Muhîtu'l-Burhânî, 3/578; Kâsânî, Bedâiu's-sanâi', 4/35-37; Mergînânî, el-Hidâye, 2/293; Zeylâî, Tebyînül-hakâik, 3/64; Babertî, el-İnâye, 4/418; Aynî, elBinâye, 5/703; Molla Hüsrev, Dürerü'l-hükkâm, 1/419; İbnü'l-Hümâm, Fethü'l-kadîr, 4/ 418; İbn Nüceym, Bahrü'r-râik, 4/224-225; Haskefî, ed-Dürrü'l-muhtâr, 1/264; İbn Âbidîn, Reddü'l-Muhtâr, 3/623-624; Meydânî, el-Lübâb, 3/105.

89 Çatalcalı Ali Efendi, Fetâvâ-yı Ali Efendi (Pertevniyal, 345), 1/124.

90 TMK, "Madde 365".

91 Tekinay, Türk Aile Hukuku, 466; Ruhi, Yargitay İçtihatlarıyla Nafaka Hukuku, 86; Ateş, "Ergin Akrabaya Karşı Nafaka Yükümlülüğü”, 22; Kaymak-Erol, “Ebeveyn Nafakası”, 461. 


\subsection{Nafaka Sorumluluğunu Doğuran ve Düşüren Haller}

Hanefî hukukçulara göre usûlün nafaka hakkı, gerekli şartları taşıdığında kendiliğinden doğar. Bu sebeple usûl, mahkeme kararı olmadan altsoydan nafaka talep edebilir, hatta nafakası karşılanmadığı zaman altsoyun malından ihtiyacı kadarını alabilir. Çünkü usûle karşı nafaka yükümlülüğü taraflar arasındaki cüz’iyyet ilişkisine dayandığı için babanın böyle bir tasarrufta bulunabileceği düşüncesi benimsenmiştir. Ancak diğer akrabaların ya da hısımların mahkeme kararı olmadan böyle bir tasarrufta bulunma hakları yoktur. Zira usûl ile diğer akrabaların nafakası, mahiyet itibariyle birbirinden farklıdır. Usûlün nafakası bakım nafakası kapsamında iken, diğer akrabalarınki yardım nafakası türündedir. Bu yüzden usûlün nafaka hakkı mahkeme kararına ihtiyaç olmadan kendiliğinden doğar iken, diğerlerinin nafaka hakkı ancak mahkeme kararılla sabit olur. ${ }^{92}$

Hanefîlere göre mahkeme tarafından takdir edilen nafaka bedeli kişinin zimmetinde borç olarak sabit olmadığı için geçmiş döneme ait olan nafakalar düşmekte ve daha sonra bunlar yükümlüden talep edilmez. ${ }^{93}$ Buradaki zaman aşımının süresi de bir ay olarak takdir edilmiştir. ${ }^{94}$ Şayet mahkemenin takdir ettiği nafakanın üzerinden bir ay geçerse, bu durumda önceki ayın nafakası düşer ve kişinin bunu isteme hakkı ortadan kalkar. Ancak hâkim, nafakalarının karşılanabilmesi için anne-babanın belirli bir miktar çocukları adına borç almasına (istidâne) izin verirse, bu durumda nafaka düşmez. ${ }^{95}$ Çünkü takdir edilen nafaka söz konusu durumda kişinin zimmetinde sabit ve kuvvetli bir alacak haline dönüşmekte ve zaman aşımından da etkilenmemektedir. Fetvâ mecmuâlarında yer alan örnekler de bu durumu desteklemektedir. Nitekim söz konusu fetvâlarda, anne ya da babanın kadıya başvurmak suretiyle kendilerine belirli bir miktar nafaka takdir ettirdikleri, bu hususta istidâneye dair izin aldıkları ve daha sonra döndükleri zaman bu borçların çocuklardan alınacağı ifade edilmektedir. ${ }^{96}$ Ancak fetvâ örneklerinde görüldüğü üzere, takdir edilen bu nafakaların tereke-

92 Kâsânî, Bedâiu's-sanâi', 4/37; Mergînânî, el-Hidâye, 2/289, 294; Burhâneddîn el-Buhârî, el-Muhîtu'lBurhânî, 3/573; Mevs11̂̂, el-îhtiyâr, 4/13; Zeylâ̂i, Tebyînül-hakâik, 3/59-60; Aynî, el-Binâye, 5/709-710; Molla Hüsrev, Dürerü'l-hükkâm, 1/417; ibn Nüceym, Bahrür-râik, 4/232-233; Damâd, Mecmaül-enhur, 1/503-504; İbn Âbidîn, Reddü'l-Muhtâr, 3/627; Meydânî, el-Lübâb, 3/108.

93 Serahsî, el-Mebsût, 5/184-185; Kâsânî, Bedâiu's-sanâi', 4/37-38; Mergînânî, el-Hidâye, 2/294; Mevslîi, el-ìhtiyâr, 4/13; Zeylâi, Tebyîül-hakâik, 3/65; Babertî, el-i̇nâye, 4/425-426; Molla Hüsrev, Dürerü'l-hükkâm, 1/421; ỉbn Nüceym, Bahrürr-râik, 4/233; i̇bn Âbidîn, Reddü'l-Muhtâr, 3/594, 633; Meydânî, el-Lübâb, 3/109. Hanefîlerin dışındaki diğer mezheplere göre ise nafakanın mahkeme tarafından takdir edilip edilmemesi sonucu değiştirmektedir. Şayet mahkeme kararı yoksa bu durumda nafaka yükümlüsünün zimmetinde ödemek zorunda olduğu bir borcun olmadığı, bu sebeple zamanında ödenmeyen nafakaların zaman aşımına uğrayacağı ve yükümlülüğün düşmesi sebebiyle alacaklının geçen süre için talep hakkının olmadığı fikri benimsenir. Buna karşın mahkeme tarafından takdir edilen bedelin zimmette borç olduğu, zamanında ödenemeyen nafakanın zaman aşımına uğramayacağı ve alacaklının bunu yükümlüden talep etme hakkının olduğu ifade edilir. Ayrıntılı bilgi için bk. Ateş, "Ergin Akrabaya Karşı Nafaka Yükümlülüğ̈ü", 24.

94 Zeylâ̂i, Tebyînül-hakâik, 3/65; ỉbnü'l-Hümâm, Fethü'l-kadîr, 4/425; i̇bn Nüceym, en-Nehrü'l-fâik, 2/524; ỉbn Âbidîn, Reddü'l-Muhtâr, 3/633-634; Meydânî, el-Lübâb, 3/109.

95 Kudûrî, el-Muhtasar, 1/174; Serahsî, el-Mebsût, 5/184-185; Haddâdî, el-Cevheratü'n-Neyyira, 2/94; Aynî, elBinâye, 5/711; İbn Nüceym, Bahrürr-râik, 4/234; Damâd, Mecmaü'l-enhur, 1/504; Meydânî, el-Lübâb, 3/109.

96 Dürrizâde Mehmed Ârif Efendi, Netîcetü'l-fetâvâ, 105-106. Anlatılan bu durum, mahkeme kayıtlarında "Hâkim târih-i kitâbdan ittibâren yevmî râyicül-beş akçe farz ve takdîr etti. Hâkim vakt-i hâcetde meblağ-ı mef- 
den alınabilmesi için istidânenin ölümden önce gerçekleşmiş olması gerekir; aksi takdirde usûl istidâne etmeden kendi imkânlarıyla geçinirken çocuk vefat ederse, bu durumda kendileri "nafaka hüccetim vardır" diyerek geçen sürenin nafakasını terekeden talep edemez. ${ }^{97}$

Daha önce de ifade edildiği üzere alt soyun nafaka yükümlüsü olabilmesi için birtakım şartların bulunması gerekmektedir. Bu şartların varlığı nafaka yükümlülüğünü doğururken, bunlardan birinin yokluğu da sorumluluğu düşürmektedir. Altsoyun nafaka ödemeyecek duruma düşmesi veya usûlün kendi ihtiyaçlarını karşılayabilecek bir imkâna kavuşması, nafaka alacaklısı olan annenin bir başkasıyla evlenmesi, ya da takdir edilen nafakanın üzerinden belirli bir sürenin geçmesi yükümlülügü düşüren haller arasında zikredilebilir. ${ }^{98}$

Usûle karşı nafaka yükümlülüğü, Türk Medeni Hukuku'nda kendiliğinden doğan bir hak değildir. Ebeveynin nafaka alabilmesi için öncelikle mahkemeye müracaat etmesi gerekir. ${ }^{99}$ Başka bir ifadeyle, kişinin hukuken "nafaka yükümlüsü" ya da "nafaka borçlusu" olabilmesi için kendisine dava açılması ve üzerine belirli bir nafakanın takdir edilmesi icap eder; aksi takdirde yargı re'sen nafakaya hükmedemez. ${ }^{100}$ Yarg1 yoluyla belirlenen bu nafakanın ödeme yükümlülüğündeki zaman aşımı süresinin de 10 yıl olarak takdir edildiği anlaşmaktadır. Nitekim Türk Borçlar Kanunu'nun 146. maddesinde belirtilen bu hüküm, mahkeme tarafından takdir edilen nafakaların zimmette borç olarak sabit olduğunu ve herhangi bir sebeple alınamayan geçmiş nafakaların üzerinden 10 yıl geçmediği sürece bunların talep edebileceğini göstermektedir. ${ }^{101}$

Türk Medeni Hukuku'nda usûlün nafakası, mahkeme kararıyla doğan bir hak olduğu için ortadan kalkması da yine aynı yolla gerçekleşmektedir. Nafaka, alacaklı tarafın yeniden evlenmesi veya taraflardan birinin ölümü ile kendiliğinden ortadan kalkarken; kişinin haysiyetsiz bir hayat sürmesi, nikâhsız bir şekilde evli gibi yaşaması veya yoksulluğunun ortadan kalkması durumlarında ise mahkeme kararıla sona erdirilir. $^{102}$

rûzu istidâne edip vakt-i zaferde mezbûra rücû‘ etmesine izin verdi." şeklinde yer alan lafizlarla standart bir ifadeye dönüşmüştür. Ayrıntılı bilgi için bk. Eyüb Mahkemesi 37 Numaralı Sicil (1047/1637-1638), 25/75; Istanbul Mahkemesi 10 Numaralı Sicil (1072-1073 /1661-1663), 51/885; Bab Mahkemesi 11 Numaralı Sicil (1081/ 1670-1671), 53/84; Rumeli Sadâreti Mahkemesi 106 Numaralı Sicil (1067-1069/ 1656-1658), 2019, 50/460; Eyüb Mahkemesi (Havass- 1 Refia) 90 Numaralı Sicil (1090-1091/1679-1680), 31/517.

97 Feyzullah Efendi, Fetâvâ-yı Feyziye (Pertevniyal, 347), 89, 114; Dürrizâde Mehmed Ârif Efendi, Netîcetü’lfetâvâ (Pertevniyal, 354), 100; Yeni Şehirli Abdullah Efendi, Behcetü'l-fetâvâ (Pertevniyal, 327), 124.

98 Serahsî, el-Mebsût, 5/222; Kudûrî, el-Muhtasar, 1/174; Semerkandî, Tuhfetü'l-Fukahâ, 2/168; Kâsânî, Bedâiu's-sanâi', 4/35-38; Kâdîhân, Fetâvâ Kâdîhân, 1/388; Mergînânî, el-Hidâye, 2/292; Mevsılî, el-İhtiyâr, 4/3, 10, 12; Zeylâî, Tebyîül-hakâik, 3/64; Aynî, el-Binâye, 5/699; İbnü'l-Hümâm, Fethü'l-kadîr, 4/423, 425; Damâd, Mecmaü'l-enhur, 1/499; Şeyhülislam Feyzullah Efendi, Fetâvâ-yı Feyziye (Pertevniyal, 347), 117, 122; Çatalcalı Ali Efendi, Fetâvâ-yı Ali Efendi (Pertevniyal, 345), 1/110; İbn Âbidîn, Reddü'l-Muhtâr, 3/621622.

99 TMK, "Madde 364".

100 Akif Genç, Türk Medeni Hukukunda Yardım Nafakası (İstanbul: İstanbul Üniversitesi, Sosyal Bilimler Enstitüsü, Yüksek Lisans Tezi, 2012), 34; Ateş, “Ergin Akrabaya Karş1 Nafaka Yükümlülüğü”, 25.

101 TBK, "Madde 146".

102 TMK, "Madde 176". 


\section{Sonuç}

Çalışmanın giriş kısmında ifade edildiği üzere, huzurevleri ile burada kalan kişilerin sayısı her geçen gün artmaya devam etmektedir. Söz konusu durumun önüne geçmek için anne ve babanın yanı sıra aile büyüklerine sahip çıkmak, onları koruyup kollamak ve ihtiyaç halinde nafakalarını temin etmek gerekir.

Anne ve babanın (usûl) nafakasını karşılamak, onları koruyup kollamak ve bakımlarını üstlenmek, her şeyden önce insani ve ahlaki bir yükümlülüktür. Ancak gerek din gerekse hukuk bu yükümlülügü insanların inisiyatifine bırakmayarak gereken düzenlemeleri yapmış ve gerektiğinde zorla ifasını da sağlamıştır. Dolayısıyla ebeveyne karşı nafaka sorumluluğu, ahlâkî bir görev olmanın da ötesinde bağlayıcılı̆̆ı olan hukuki bir yükümlülüktür. Ancak bu sorumluluğun oluşabilmesi için birtakım şartlar vardır.

Usûlün nafaka alacaklısı olabilmesi için öncelikle fakir olması gerekir. Hanefîler, usûlün nafaka alabilmesi için fakir olmalarının tek başına yeterli olduğunu, sağlıklı ve çalışma imkânı yerinde olan ebeveynlerin nafakasının altsoy tarafından karşılanacağ1 görüşünü benimsemektedir. Alt soyun ebeveyne karşı nafaka yükümlülügüunde ise, zenginlik şartı aranır; ancak bunun ölçüsünün ne olacağı hususu tartışmalıdır. Ebû Yûsuf'a göre burada kastedilen zenginliğin ölçüsü nisap miktarı iken, İmam Muhammed kişinin çalışıp kazanmaya güç yetirebiliyor olmasını, yani ödeme imkânını dikkate almaktadır.

Alt soyun fakir olması, usûle karşı nafaka yükümlülüğünü ortadan kaldırır; ancak fakir ve muhtaç olan ebeveynin hasta ve yatalak olup herhangi bir kazanıcının olmaması farklı değerlendirilmiştir. Hanefî mezhebinde zâhirü'r-rivâye olan görüşe göre, çocuğun geçimini sağlamaya çalıştığı bir ailesi varsa, böyle bir durumda fakir olan kişinin bakıma muhtaç olan anne ve babasını yanına alarak nafakasını paylaşması gerekir.

Aslında genel kurala (kıyas) göre, din farklılığı nafaka hukukunun oluşmasına mâni olsa da Hanefîler istihsan yoluyla anne ve babanın durumunu genel kuraldan istisna etmiştirler. Buna göre usûle karşı nafaka sorumluluğunda taraflardan birinin farklı dine mensup olması yükümlülüğü ortadan kaldırmaz, ancak Hanefî mezhebinde bu kuralın sadece zimmî ile Müslüman arasında geçerli olduğu kabul edilmektedir.

Hanefî hukukçulara göre usûlün nafaka hakkı, gerekli şartları taşıdığında kendiliğinden doğar, bu yükümlülüğün sübutu için hâkimin hükmüne ihtiyaç yoktur. Bu yüzden ebeveynler, mahkeme kararı olmadan nafakalarını talep edebilir ve gerektiğinde çocuklarının mallarından alabilir. Ancak usûle tanınan bu tasarruf yetkisi, mutlak bir hak olmaktan çok kişinin ihtiyacıyla sınırlıdır.

Usûlün nafakasının karşılanmasında oldukça hassas bir tavır sergilenmiştir. Osmanlı fetvâ mecmuaları ile şer'iyye sicillerinde yer alan örnekler, somut bir şekilde bu durumu ortaya koymaktadır. Öyle ki, söz konusu örneklerde çocukların nafaka bırakmadan uzak bir yere gitmeleri durumunda ebeveynin kadıya başvurmak suretiyle günlük kendilerine belirli bir miktar nafaka takdir ettirdikleri, bu hususta istidâneye dair izin aldıkları ve daha sonra döndükleri zaman bu borçların çocuklardan alınacağı ifade edilmiştir. 
Nafakanın kapsamıyla ilgili farklı görüşler bulunmakla birlikte bunun belirli bir miktar ile sınırlandırılması mümkün değildir. Nitekim Hanefîlerin de içinde bulunduğu çoğunluk, nafaka konusunda her iki tarafın durumuna bakılması gerektiğini, zaman, mekân ve ahvalin değişmesiyle nafaka miktarının da değișebileceğini ifade etmektedirler. Bu yüzden, nafakanın kapsamı belirlenirken öncelikle örf ve âdet ile dönemin koşullarına bakılması ve bu hususların dikkate alınması gerekir. Dolayısıyla nafakanın kapsamında örfün önemli ve belirleyici bir etkisinin olduğunu unutmamak gerekir.

Hanefîlere göre usûlün nafakasında cüz'iyyet vasfı, sıralamada ise yakınlık derecesi dikkate alınmaktadır. Bu yüzden daha yakındaki fürû' var iken uzakta olan kişi nafaka ile yükümlü tutulamaz. Ekonomik durumu yerinde olan çocuklar fakir ve muhtaç durumda olan ebeveynlerinin nafakasından sorumlu olurlar. Hanefî mezhebinde çocukların mirastaki paylarına göre sorumlu olacağını ifade eden bir görüş mevcut olmakla birlikte sahih olan görüşe göre bunun bir önemi yoktur, buradaki temel kural yakınlık ve cüz'iyyettir. Cinsiyet farkının bu ilişkiye herhangi bir etkisi olmadığı için de erkek ve kız çocuklar usûlün nafakasından eşit bir şekilde sorumlu olurlar.

Hanefîlere göre nafaka, mahkeme kararıyla takdir edilmiş olsa da belirlenen bedel kişinin zimmetinde borç olarak sabit olmamaktadır. Bu yüzden geçmiş döneme ait olan nafakalar düşmekte ve daha sonra bunlar çocuklardan talep edilememektedir. Buradaki zaman aşımının süresi, bir ay olarak takdir edilmektedir. Şayet mahkemenin takdir ettiği nafakanın üzerinden bir ay geçerse, bu durumda önceki ayın nafakası düşer ve kişinin bunu isteme hakkı olmaz. Ancak hâkim, anne-babanın çocukları adına borç almasına (istidâne) izin verirse, bu durumda nafaka düşmez. Bununla birlikte altsoyun nafaka ödeyemeyecek duruma düşmesi veya usûlün kendi ihtiyaçlarını karşılayabilecek bir imkâna kavuşması, nafaka alacaklısı olan annenin bir başkasıyla evlenmesi ya da takdir edilen nafakanın üzerinden belirli bir sürenin geçmesi halinde yükümlülük düşmektedir.

\section{Kaynakça}

Akıntürk, Turgut - Ateş, Derya. Türk Medeni Hukuku Aile Hukuku. İstanbul: Beta Yayınları, 2019. Akıntürk, Turgut. Türk Medeni Hukuku Aile Hukuku. İstanbul: Beta Yayınları, 2006.

Akyıldırım, Taylan. 259 Numaralı Şer iyye Sicili Defterine Göre Galata. İstanbul: Mimar Sinan Üniversitesi, Sosyal Bilimler Enstitüsü, Yüksek Lisans Tezi, 2010.

Ali Haydar Efendi, Küçük. Dürerü'l-hükkâm şerhu Mecelleti'l-ahkâm. 4 Cilt. İstanbul: Matbaaa-i Tevsi-i Tibaat, 1330.

Ateş, Üveys. "İslâm Hukukunda ve Türk Medeni Hukukunda Ergin Akrabaya Karşı Nafaka Yükümlülüğü”. FSM İlmi Araștırmalar İnsan ve Toplum Bilimleri Dergisi 13 (Haziran 2019), 1-31. https://doi.org/10.16947/fsmia.582334

Aynî, Ebû Muhammed Bedreddin Mahmud b. Ahmed b. Musa. el-Binâye fi şerhi'l-hidâye. 13 Cilt. Beyrut: Dâru'l-Kütübi'l-illmiyye, 1420.

Bab Mahkemesi 11 Numaralı Sicil (1081/ 1670-1671). ed. Coşkun Yılmaz. İstanbul: Kültür AŞ. Yayınları, 2019. http://www.kadisicilleri.org/index.php. 
Babertî, Ekmelüddin Muhammed b. Mahmud. el-İnâye şerhu'l-hidâye. 10 Cilt. Beyrut: Dâru'l-Fikir, ts.

Bakırcan, Sariye Abay. İslam-Osmanlı Hukukunda Nafaka: İstanbul Bab Mahkemesi Örneği. İstanbul: Marmara Üniversitesi, Sosyal Bilimler Enstitüsü, Yüksek Lisans Tezi, 2013.

Bilmen, Ömer Nasuhi. Hukuku İslâmiyye ve Istılahatı Fıkhiyye Kamusu. 8 Cilt. İstanbul: Bilmen Yayınevi, 1968.

Buhârî, Burhâneddîn (Burhânüşşerîa). el-Muhîtu'l-Burhânî fi'l-fikhi'n-Nu'mânî. 9 Cilt. Beyrut: Dâru'l-Kütübi'l-i̇lmiye 1424.

Çatalcalı, Ali Efendi. Fetâvâ-yı Ali Efendi. İstanbul: Süleymaniye Kütüphanesi, Pertevniyal, 345. 2738.

Çelik, Özlem. İslam Hukukun da Hısımlık Nafakası Mükellefiyetinde Din Farkı. Ankara: Ankara Üniversitesi, Sosyal Bilimler Enstitüsü, Yüksek Lisans Tezi, 2013.

Çiğdem, Recep. Mukayeseli Medeni Hukuk. İstanbul: Rağbet Yayınları, 2012.

Çolak, Abdullah. İslâm Aile Hukuku. Malatya: Yılmaz Yayıncılık, 2016.

Dürrizâde, Mehmed Ârif Efendi. Netîcetül-fetâvâ maa'n-nukûl. İstanbul: Süleymaniye Kütüphanesi, Pertevniyal, 354. 2-639.

Erbay, Celal. "Nafaka”, Türkiye Diyanet Vakfi İslâm Ansiklopedisi. 32/282-285. İstanbul: TDV Yayınları, 2006.

Erbay, Celâl. İslâm Hukuku'nda Evlilik ve Hısımlık Nafakası: Kitâbu'n-Nafakat ve Türk Yargı Kararları ile Mukayeseli Olarak. Bakü: Göytürk Neşriyat, 1995.

Erkan Nevzat. Osmanlı Üsküdar'inda Toplumsal Hayat. İstanbul: Üsküdar Belediyesi, 2015.

Erkan, Nevzat. “Arşiv ve Mahkeme Kayıtlarına Göre Osmanlı Payitahtında Yaşlı Olmak (16-18. Yüzy1llar)”, Diyanet İlmi Dergi 56/1 (Mart 2020). 123-146.

EYHGM, Engelli ve Yaşlı Hizmetleri Genel Müdürlüğü (EYHGM). Engelli ve Yaşlı İstatistik Bülteni (Mart 2021), 1-56.

Eyüb Mahkemesi (Havass-ı Refia) 90 Numaralı Sicil (1090-1091/ 1679-1680), haz. Fuat Recep vd., İstanbul: İSAM Yayınları, 2011. http://www.kadisicilleri.org/index.php.

Eyüb Mahkemesi 37 Numaralı Sicil (1047/ 1637-1638). haz. Salih Kahriman, vd., İstanbul: İSAM Yayınları, 2011. http://www.kadisicilleri.org/index.php.

Eyüb Mahkemesi 90 Numaral Sicil (1090-1091 / 1679-1680). haz. Fuat Recep vd., İstanbul: İSAM Yayınları, 2011. http://www.kadisicilleri.org/index.php.

Feyyûmî, Ebü'l-Abbas Ahmed b. Muhammed b. Ali el-Hamevî. el-Misbâhü'l-münîr fi Garîbi'şŞerhi'l-Kebîr. Beyrut: el-Mektebetü'l-ilmiyye, ts.

Feyzioğlu, Necmeddin Feyzi. Aile Hukuku. İstanbul: Fakülteler Matbaası, 1979.

Genç, Akif. Türk Medeni Hukukunda Yardım Nafakası. İstanbul: İstanbul Üniversitesi, Sosyal Bilimler Enstitüsü, Yüksek Lisans Tezi, 2012.

Haddâdî, Ebû Bekr Ali b. Muhammed. el-Cevheratü'n-Neyyira. 2 Cilt. el-Matbaatü'l-Hayriyye, 1322.

Haskefî, Muhammed b. Ali b. Muhammed b. Ali b. Abdurrahman. ed-Dürrül-muhtâr şerhu Tenvîri'l-ebsâr ve câmi'i'l-bihâr, thk. Abdülmun'im Halil İbrahim. Beyrut: Dârü'l-Kütübi'lİlmiyye, 2002.

İbn Âbidîn, Muhammed Emîn. Reddü'l-Muhtâr ale'd-Dürri'l-muhtâr. 6 Cilt. Beyrut: Dâru'lFikir,1412.

İbn Kudâme, Ebü'l-Ferec Şemsüddîn Abdurrahmân b. Muhammed el-Makdisî. el-Muğnî. 10 Cilt. Kahire, Mektebetü'l-Kahire, 1388/1968.

İbn Manzûr, Ebû'l-Fazl Muhammed b. Mükerrem. Lisânül-Arab, nşr. Emin Muhammed Abdülvehhâb, Muhammed es-Sadık el-Ubeydî. Beyrut: Dâru Sâdır, 1414. 
İbn Nüceym, Siracüddîn Ömer b. İbrahim. en-Nehrü'l-fâik Şerhu Kenzi'd-Dekâik, thk. Ahmed Azvu İnâye. 3 Cilt. Beyrut: Dâru'l-Kütübi'l-İlmiyye, 2002.

İbn Nüceym, Zeynüddîn b. İbrâhîm. Bahrü'r-râik şerhü Kenzi'd-Dekâik. 8 Cilt. Kahire: Dâru'lKitâbi'l-İslâmî, ts.

İbnü'l-Hümâm, Kemalüddîn es-Sivâsî. Fethü'l-kadîr. 10 Cilt. Beyrut: Dâru'l-Fikr, ts.

İstanbul Mahkemesi 10 Numaral Sicil (1072-1073 /1661-1663). ed. Coşkun Yılmaz. İstanbul: Kültür AŞ. Yayınları, 2019.

Kâdîhân, Ebü'l-Mehasin Fahreddin Hasan b. Mansur b. Mahmûd. Fetâvâ Kâdîhân fi mezhebi'lİmâmi'l-A'zam Ebî Hanîfete'n-Nu'mân. nşr. Salim Mustafa el-Bedrî. 3 Cilt. Beyrut: Dârü'lKütübi'l-İlmiyye, 2009.

Kahveci, Nuri. İslâm Aile Hukuku. İstanbul: Hikmetevi Yayınları, 2014.

Kal'aci, Muhammed Revvas. el-Mevsû'atü'l-fikhiyyetü'l-müyessere. Beyrut: Dârü’n-Nefâis, 2000.

Kal'acî, Muhammed Revvâs - Kanîbî, Hâmid Sâdık. Mu'cemü lugati'l-fukahâ. Beyrut: Dâru'nNefâis, 1988.

Karslı, Emine. "Modernleşme Sürecinde Çözülen Aile Yapısı ve Kadının Yeniden İnşası”. Uluslararası Hukuk ve Sosyal Bilim Araştırmaları Dergisi 1/1(Temmuz 2019), 1-14.

Kâsânî, Alâüddîn Ebû Bekir. Bedâiu's-sanâi' fi tertibi'ş-şerâi'. 7 Cilt. Beyrut: Dâru'l-Kütübi'lİlmiyye, 1986.

Kaymak, Fethiye Birsen - Erol, Ayten. "İslâm Aile Hukukunda Hısımlık İlişkisi Bakımından Ebeveyn Nafakası”. Kalemname 5/10 (Aralık 2020), 444-471.

Köse, Saffet. "İslâm Açısından Ebeveynin Çocukları Üzerindeki Hakları veya Çocukların Ebeveynine Karşı Vazifeleri”. İslam Hukuku Araştırmaları Dergisi 12 (2008), 345-368.

Kudûrî, Ebü'l-Hüseyn. el-Muhtasar. Beyrut: Dâru'l-Kütübi'l-ìlmiyye, 1418/1997.

Mergînânî, Burhâneddin Ali b. Ebî Bekr. el-Hidâye şerhu bidâyeti'l-Mübtedî. 4 Cilt Beyrut: Dâru İhyâi't-Türâsi'l-Arabî, ts.

Mevsilî, Mecdüddîn Abdullah b. Mahmûd. el-İhtiyâr li-ta'lîli'l-Muhtâr. 5 Cilt. Beyrut: Dâru'lKütübi'l-ïlmiye, 1937/1356.

Meydânî, Abdulganî el-Ganimî ed-Dimeşkî. el-Lübâb fî şerhi'l-kitâb, thk. Muhammed Muhyiddîn Abdülhamid. 4 Cilt. Beyrut: el-Mektebetü'l-i̇lmiyye, ts.

Molla Hüsrev, Muhammed b. Ferâmuz. Dürerü'l-hükkâm fî şerhi Gureri'l-ahkâm. 2 Cilt. Kahire: Dârû İhyâi'l-Kütübi'l-Arabiyye, ts.

Nevevî, Ebû Zekeriya Muhyiddîn Yahya b. Şeref. Ravzatü't-tâlibîn ve umdetü'l-müftîn, thk. Züheyr eş-Şâvîş. 12 Cilt. Beyrut: el-Mektebü'l-i̇slâmî, ts.

Özcan, Ruhi. İslâm Hukuku'nda Hısımlık Nafakası. İzmir: Çağlayan Yayınları, 1996.

Ruhi, Ahmet Cemal. Yargıtay İçtihatlarıyla Nafaka Hukuku. İstanbul: Seçkin Yayınları, 2010.

Rumeli Sadâreti Mahkemesi 106 Numaral Sicil (1067-1069/ 1656-1658). ed. Coşkun Y1lmaz. İstanbul: Kültür AŞ. Yayınları, 2019. http://www.kadisicilleri.org/index.php.

Sa'dî, Ebû Ceyb. el-Kâmûsü'l-fikhî luğaten ve ıstılâhan. Dımeşk: Dâru'l-Fikr, 1988.

Semerkandî, Alâeddin. Tuhfetü'l-Fukahâ. Beyrut: Dâru'l-Kütübi'l-ílmiyye, 1984.

Serahsî, Şemsü'l-eimme. el-Mebsût. 30 Cilt. Beyrut: Dâru'l-Kütübi'l-i̇lmiyye, 1993.

Şeyhîzâde, Damad Efendi. Mecmaü'l-enhur fî şerhi Mülteka'l-ebhur. thk. Halil İmran el-Mansur. 2 Cilt. Beyrut: Dârü'l-Kütübü'l-i̇lmiyye, 1998.

Şeyhülislam Feyzullah Efendi. Fetâvâ-yı Feyziye. İstanbul: Süleymaniye Kütüphanesi, Pertevniyal, 347. 2-572.

Tekinay, Selahattin Sulhi. Türk Aile Hukuku. İstanbul: Beta Basım Yayım Dağıtım, 1984.

Topuksak, Zümra. Yardım Nafakası. İstanbul: İstanbul Üniversitesi, Sosyal Bilimler Enstitüsü, Yüksek Lisans Tezi, 2011. 
Yeni Şehirli Abdullah Efendi. Behcetü'l-fetâvâ. İstanbul: Süleymaniye Kütüphanesi, Pertevniyal, 327. 2-643

Zebîdî, Ebü'l-Feyz Murtazâ Muhammed b. Muhammed. Tâcü'l-arûs min cevâhiri'l-kâmûs. Kuveyt: Dâru'l- Hidâye, ts.

Zeylaî, Osmân b. Alî. Tebyînül-hakâik fi Şerhi Kenzi'd-dekâik. 6 Cilt. Bulak: el-Matbaatü'l-Kübrâ elEmiriyye, 1313. 